This item is the archived peer-reviewed author-version of:

Board level IT governance : a scoping review to set the research agenda

\title{
Reference:
}

Caluw e Laura, De Haes Steven.- Board level IT governance : a scoping review to set the research agenda Information systems management - ISSN 1058-0530 - Boca raton, Auerbach publications, 2019, 36:3, p. 262-283 Full text (Publisher's DOI): https://doi.org/10.1080/10580530.2019.1620505

To cite this reference: https://hdl.handle.net/10067/1599990151162165141 


\section{Board Level IT Governance: A Scoping Review to Set the}

\section{Research Agenda}

Laura Caluwe, University of Antwerp - Antwerp Management School, Antwerp, Belgium, Laura.caluwe@uantwerpen.be (corresponding author)

Steven De Haes, University of Antwerp - Antwerp Management School, Antwerp, Belgium, Steven.dehaes@uantwerpen.be 
L. Caluwe and S. De Haes

\section{ABSTRACT}

Digital transformation is becoming pervasive, resulting in the intertwine of organizational strategy with IT strategy and increasing importance of IT risk. This falls into the domain of the board of directors, who are ultimately accountable for strategy and control. Yet, research shows that the involvement of boards in governing digital assets is low. In order to address this topic, this paper summarizes the state-of-the-art of this research domain and identifies an agenda for future research.

Keywords: IT Governance, Board of Directors, Literature Review, Corporate Governance, Research Agenda 


\section{PROBLEM STATEMENT AND RESEARCH QUESTION}

Given the centrality of IT for enterprise risk management and value generation in digitized organizations, a specific focus on IT governance has arisen over the last two decades (De Haes and Van Grembergen, 2009; Thorp, 2003; Wilkin and Chenhall, 2010). IT governance "is an integral part of corporate governance and addresses the definition and implementation of processes, structures and relational mechanisms in the organization that enable both business and IT people to execute their responsibilities in support of business/IT alignment and the creation of business value from IT-enabled business investments" (De Haes and Van Grembergen, 2015).

Early IT governance research primarily focused on how to optimally organize the IT function. With the turn of the century, this focus shifted to the alignment of business and IT. In recent years, emerging research calls for more board level engagement in IT governance. Board level IT governance research identifies serious consequences for digitized organizations in case the board is not involved in setting direction towards and being in control of the digital assets. Additionally, empirical evidence shows that board level IT governance enables better organizational performance while managing the business risks of the organization. Turel and Bart (2014) conclude that high levels of board level IT governance, regardless of existing IT needs, will improve organizational performance. Valentine and Stewart (2015) report on the superior financial performance of companies with a comprehensive digital leadership function, both in terms of performance $(+9 \%)$ and profitability $(+23 \%)$ and in terms of a greater market valuation $(+12 \%)$. Regarding risk drivers, there is a need to comply with an increasing amount of regulatory and legal requirements of which many also impact IT (Butler and Butler, 2010; Trautman and Altenbaumer-Price, 2010). As such, these regulatory requirements redefine director responsibilities for IT governance (Trites, 2004). Additionally, the continuity of reliability of most primary and secondary business processes relies heavily on IT (Parent and 
Reich, 2009). Therefore, the board can no longer delegate all control regarding business risk resulting from IT to IT professionals (Raghupathi, 2007; Trites, 2004).

Notwithstanding the empirically demonstrated importance of board level IT governance, other studies point out that on average the involvement of boards in IT governance is low. Less than $20 \%$ of the boards are taking up accountability for governing their digital assets (Andriole, 2009; Bart and Turel, 2010; O'Donnell, 2004; Valentine and Stewart, 2015), suggesting there is a knowing-doing gap. The goal of this research is to address this knowing-doing gap by summarizing existing board level IT governance research and identifying opportunities for future research. Therefore, the following general research question is put forward:

"What is the state-of-the-art of the research domain of board level IT governance?"

In order to answer this general research question in a structured and rigorous way, three more specific research questions were formulated. The first research question examines the antecedents of board level IT governance, or in other words, why certain boards are more involved in IT governance than others. The second research question addresses the issue of how to implement board level IT governance. In accordance with the IT governance definition by De Haes and Van Grembergen (2015), governance practices, and more specifically structures, processes and relational mechanisms, that can be used to deploy IT governance at the level of the board are identified. The third and last research question highlights the value of board involvement in IT governance, i.e., the consequences thereof. A visual depiction of these research questions is shown in Figure 1. 


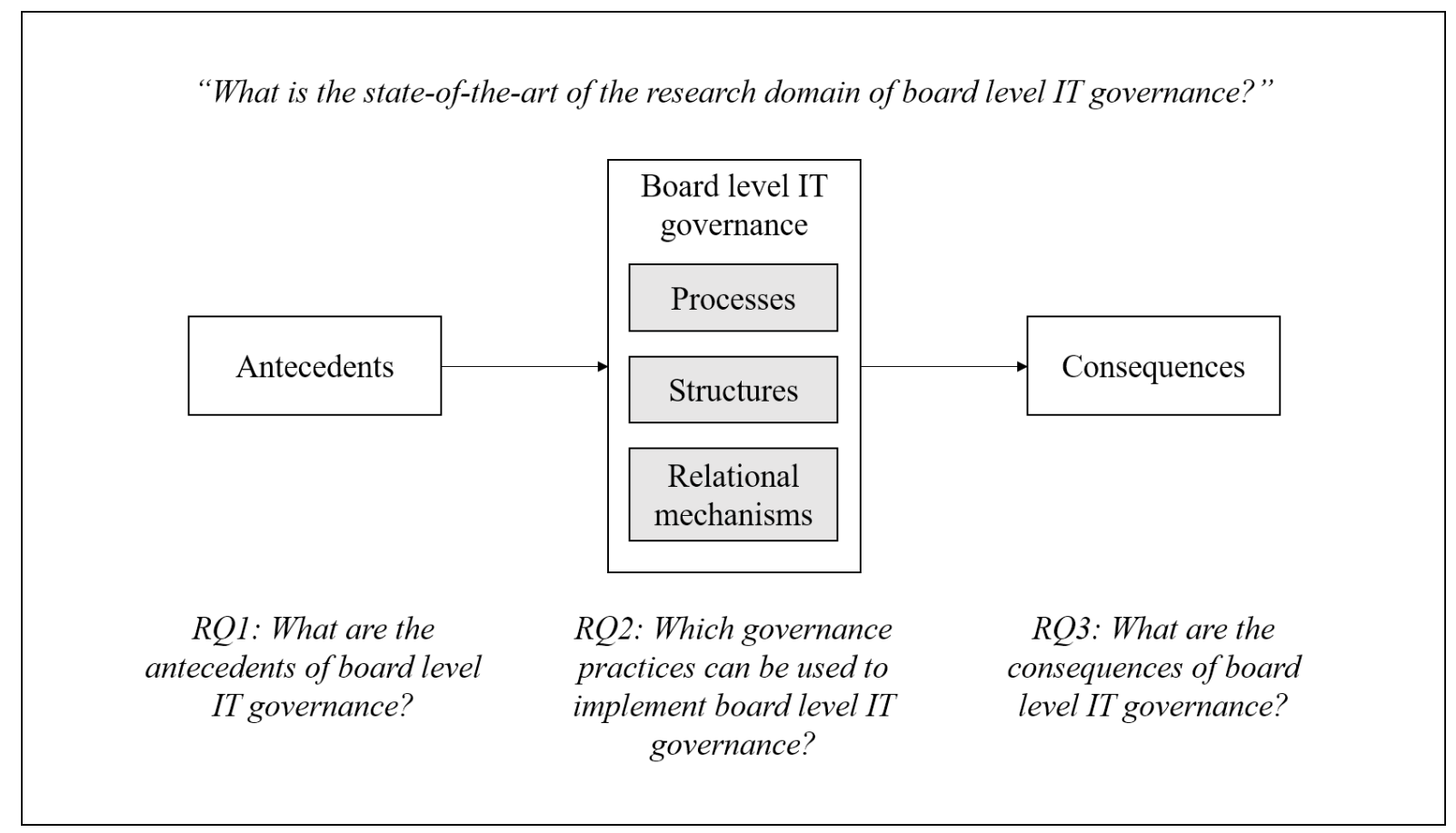

Figure 1 Research questions 


\section{KEY CONCEPTS}

In this section, we will briefly define and discuss the board of directors, corporate governance and IT governance and explain how the concept of board level IT governance fits into these research streams.

\section{Board of directors and corporate governance}

The board of directors, commonly referred to as "the board", is a formal body that oversees all activities of an organization. The system of rules and practices by which they direct and control the organization is referred to as 'corporate governance'. The Organization for Economic Cooperation and Development (OECD) states that "corporate governance involves a set of relationships between a company's management, its board, its shareholders and other stakeholders. Corporate governance also provides the structure through which the objectives of the company are set, and the means of attaining those objectives and monitoring performance are determined. ”

Different board structures can be identified. Either a board applies a two-tier structure or a unitary structure. Two-tier boards consist of a "supervisory board" that is composed of nonexecutive directors (directors that are not part of the executive management), and a "management board" that is composed of executive directors (directors that are part of the executive management). Unitary boards are composed of both executive and non-executive directors (Cadbury, 1992; OECD, 2015). This difference between a two-tier and a unitary board structure should be kept in mind, as it is possible that various studies might refer to "the board" and not refer to exactly the same concept (i.e. they could be referring to the supervisory board only).

Boards of directors perform control, service and resource dependence roles in an organization (Johnson, Daily, \& Ellstrand, 1996). The control function is derived from agency theory, which 
defines two actors: the principal, who is the task-assigning actor, and the agent who is the taskexecuting actor. According to agency theory, in a context of separation of ownership and control, conflicts can arise due to different levels of risk acceptance and differing interests (Eisenhardt, 1989; Jensen and Meckling, 1976). The board should control for the self-interest of executive management (the agent) and protect stakeholder interests (the principal) (Hillman and Dalziel, 2003). The service task of the board consists of providing advice and counsel to the chief executive officer (CEO) (Forbes and Milliken, 1999; Johnson, et al., 1996). Lastly, in accordance with the resource-based view of the firm and the resource dependence theory, directors can be valuable resources in terms of competencies and facilitating access to resources for the firm, hence their resource dependence role (Daily, Dalton, \& Cannella, 2003; Huse, 2005; Johnson, et al., 1996). Indeed, the board of directors provides a certain "board capital", which includes human capital (experience, expertise) and relational capital (network of ties and reputation), which supports their control, service and resource dependence roles (Hillman and Dalziel, 2003).

\section{IT governance}

IT governance, otherwise referred to as "enterprise governance of IT" or "corporate governance of IT", is a focus area of corporate governance that is concerned with an organization's IT assets. Analogously to corporate governance, it is concerned with the oversight of IT assets and their contribution to business value and the mitigation of IT-related risks (Weill and Ross, 2004). Drawing on corporate governance, researchers in contemporary IT governance literature take a holistic approach on IT governance, acknowledging that it can be implemented using a set of structures, processes, and relational mechanisms (Peterson, 2004; Van Grembergen and De Haes, 2009; Weill and Ross, 2004). IT governance structures consist of the units and roles responsible for IT decision-making and connecting business and IT management decisionmaking functions, such as an IT steering committee. IT governance processes concern the 
formalization of procedures relating to IT decision-making and monitoring e.g., portfolio management. Relational mechanisms are those practices that facilitate collaboration among corporate executives, IT management and business management, like the co-location of business and IT personnel (De Haes and Van Grembergen, 2015).

We have chosen to adopt the IT governance definition by De Haes and Van Grembergen (2015), and consequently the perspective of structures, processes and relational mechanisms, as it explicitly positions IT governance as a responsibility of the board of directors. Yet, although the focus on structures, processes and relational mechanisms is widely accepted in IT governance literature, some researchers do criticize this perspective. Hoogervorst (2009) argues that the idea of this trichotomy is too simplistic to deal with the complexity and dynamics of organizations and IT and that it comes with a lack of attention for unified and integrated design. He suggests organizations should focus on design- and competence-oriented governance. The term 'enterprise governance' is proposed, which is defined as 'the organizational competence for continuously exercising guiding authority over enterprise strategy and architecture development and the subsequent design, implementation and operation of the enterprise" (Hoogervorst, 2009). Hoogervorst (2009) considers such governance to be essential to deal with complexity and to establish unified and integrated design. Ciborra et al. (2000) criticize the focus on control systems. The authors argue that control is difficult, if not impossible, to achieve due to factors such as the turbulence of the environment and the power of the installed base. Governance should be adapted to deal with the characteristics of these circumstances, otherwise it will fail. Smits and van Hillegersberg (2015) provide yet another perspective and argue that current IT governance literature is too focused on processes and structures, and more attention should be payed to the human or social aspects of governance. As such, the authors created a maturity model with four domains: structure, process, collaboration and behavior. Although we take the definition by De Haes and 
Van Grembergen (2015) as a starting point, leveraging this definition's connection to the role of the board, we take an open perspective to cover elements related to the lines of critique as mentioned above.

\section{Board level IT governance}

IT governance is an integral part of corporate governance, implying the involvement of the board of directors (De Haes and Van Grembergen, 2015). Indeed two research streams can be identified in IT governance literature - IT governance at managerial-level and IT governance at the level of the board of directors (Jewer and McKay, 2012). The former focuses on the IT decision-making structures at managerial-level and the contingencies that determine the best way to implement IT governance (A. E. Brown and Grant, 2005). The latter has gained more and more attention over the years. Board level IT governance research addresses the role of the board in IT-related strategic decision-making and control.

In accordance with corporate governance literature, agency theory is the most widely used theoretical perspective to examine board level IT governance (Benaroch and Chernobai, 2017; Best and Buckby, 2007; Mähring, 2006; Posthumus and von Solms, 2008; Yayla and Hu, 2014), suggesting a focus on the control function of boards regarding IT. Many researchers also build on the resource-based view of the firm (Héroux and Fortin, 2018; Turel and Bart, 2014; Valentine and Stewart, 2013b) and the resource dependence theory (Benaroch and Chernobai, 2017; Yayla and $\mathrm{Hu}, 2014)$ to examine board level IT governance, implying that boards and board members are potentially valuable resources for the governance of IT. The contingency theory is mentioned as well (Bart and Turel, 2010; Héroux and Fortin, 2018; Turel and Bart, 2014), as there is no one best way to implement or shape board level IT governance. Jewer and McKay (2012) combine institutional and strategic choice theory to explain the antecedents and consequences of board level IT governance. They suggest that a boards' way to deal with IT governance depends on the institutional pressures that influence the 
organization and the strategic choices of the board. Other theories mentioned are stewardship theory (Turel and Bart, 2014), explaining the need for boards that provide advice to managers which are considered trustworthy stewards of the organization and stakeholder theory, suggesting boards should be responsible for the oversight of the main IT resources in support of all organization stakeholders (Best and Buckby, 2007). Higgs, Pinsker, Smith, \& Young (2016) refer to signaling theory when they argue that board involvement in IT indicates this is a high priority and thus can be used to send a positive signal to the stock market, possibly influencing stock returns. Lastly, Héroux and Fortin (2018) apply upper echelon theory to explain the association between IT performance and specific characteristics of the people at the upper-level of the organization, such as board members. These different theoretical paradigms used in board level IT governance research imply several roles of the board of directors in governing IT. More specifically, they suggest a control, service and resource dependence role, as is proposed in corporate governance literature. Furthermore, board level IT governance seems to be dependent on several factors, including institutional pressures and board's decisions. Lastly, these theories suggest board level IT governance outcomes, such as changes in IT performance and impact on stock returns.

\section{RESEARCH METHOD}

A scoping review was conducted to answer the research questions that are put forward. As our goal is to summarize research findings and create an agenda for future research, a scoping review is perfectly suited (Arksey and O'Malley, 2005). In order to rigorously conduct this review, the methodological framework created by Arksey and O'Malley (2005) will be applied, also taking into consideration the recommendations made by Daudt, van Mossel, \& Scott (2013) and Levac, Colquhoun, \& O'Brien (2010). The framework describes the five research steps of a scoping review. Figure 2 shows a summary of these research steps and how they were applied in this review. 


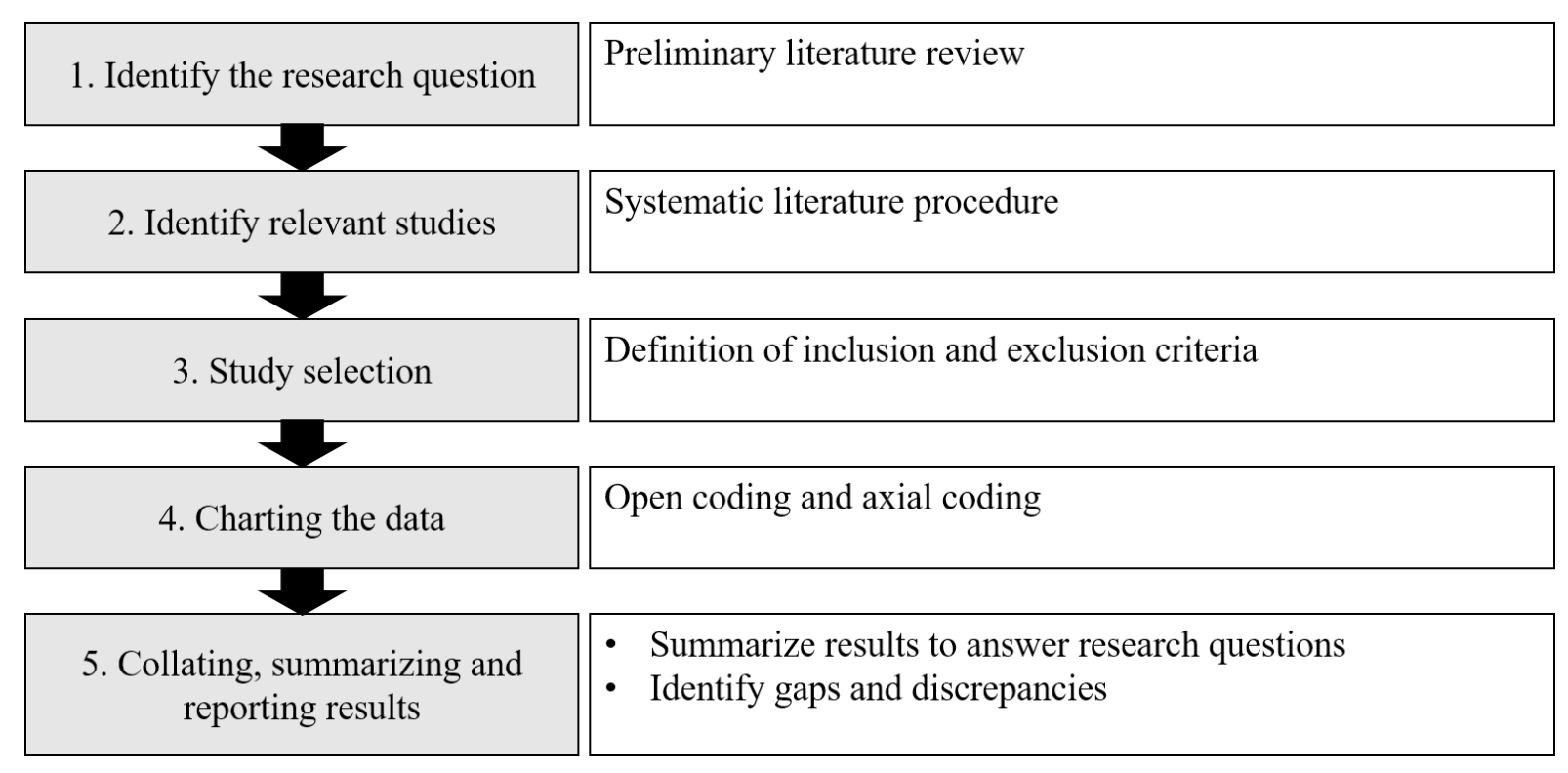

\section{Figure 2 Application of scoping review methodological framework}

The first step consists of the identification of the research question(s). The main research question "What is the state-of-the-art of the research domain of board level IT governance?" is broken down into more specific research questions. In order to ensure relevance of the research questions, a preliminary literature review was conducted. First, the corporate governance literature was scanned to find a structure that could serve as a backbone for this review. The corporate governance domain was chosen as it is closely linked to IT governance and the board of directors. The literature review of Hermalin and Weisbach (2003) was found to be fit for purpose. Their review includes three main topics: (1) the factors affecting board composition (i.e., the antecedents of board characteristics), (2) how boards accomplish their responsibilities (i.e., the implementation of their actions) and (3) the influence of the board on firm performance (i.e., the consequences of board characteristics). Second, the board level IT governance research was explored with the purpose of translating the topics as defined by Hermalin and Weisbach (2003) to IT governance. The three resulting research questions are:

1. What are the antecedents of board level IT governance?

2. Which governance practices can be used to implement board level IT governance? 
3. What are the consequences of board level IT governance?

Steps 2 and 3 consist of the identification of relevant studies and the study selection. In order to identify relevant studies to include in this review, a systematic literature procedure was designed (Kitchenham and Charters, 2007). Web of Science (WoS) and Google Scholar were searched in parallel. In order to search WoS, a specific search string was designed. This search string captured the IT governance concept as a whole, using a variety of different terms that are used to refer to this concept and the concepts "board of directors" and/or "director". Furthermore, the string specified the language (English), document types (articles or proceedings papers), indexes (Science Citation Index Expanded (SCI-EXPANDED), Social Sciences Citation Index (SSCI), Arts \& Humanities Citation Index (A\&HCI), Conference Proceedings Citation Index- Science (CPCI-S), Conference Proceedings Citation Index- Social Science \& Humanities (CPCI-SSH)) and timespan (2000-2018). This search string was ran on June $28^{\text {th }}$, 2018 and returned 48 results that day. As part of the study selection step, inclusion/exclusion criteria need to be defined to ensure that only relevant results remain for our purpose (Kitchenham and Charters, 2007). Research that does not belong to the IT governance body of knowledge (i.e., IT governance is not a central concept), that is not (at least partially) focused on board-level or director-level matters, that is not in English and/or that is not an article or a conference proceeding was excluded.

As searching WoS with a pre-designed search string will not necessarily catch all relevant research that is out there, it makes sense to consider other search strategies as well (Kitchenham and Charters, 2007). Hence, Google Scholar was searched using keywords derived from the search string that was used in WoS. Any duplicates were also removed. Following these parallel searches, forward and backward search was conducted using the database through which the research was originally retrieved. Table 1 provides an overview of the final set of papers. First, for each paper the table shows whether it is an empirical (E) (i.e., empirical 
evidence was gathered) or conceptual (C) paper. Second, the research methodology is described. Last, the table indicates whether the paper mainly focusses on the mechanisms, antecedents or consequences of board level IT governance, or in other words, to which of the three research questions the paper relates.

A fourth step in the scoping review framework consists of charting the data. Open coding and axial coding based on the research questions were used for data extraction. Open coding enabled the identification of the concepts included in board level IT governance research, while axial coding uncovered causal relationships, enabling us to relate the concepts found to the framework presented in Figure 1. (Corbin, Strauss, \& Strauss, 2014)

After charting the data, the next step consists of collating, summarizing and reporting the results (Arksey and O'Malley, 2005). Answers to the research questions were sought and gaps and discrepancies were identified, enabling the creation of an agenda for future research. 


\begin{tabular}{|c|c|c|c|c|c|}
\hline \multirow[b]{2}{*}{ Reference } & \multirow[b]{2}{*}{ 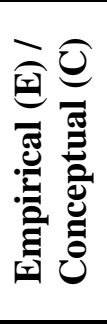 } & \multirow[b]{2}{*}{ Methodology } & \multicolumn{3}{|c|}{ Main subject } \\
\hline & & & 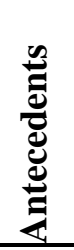 & 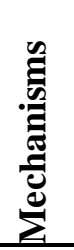 & 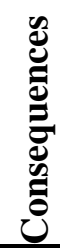 \\
\hline Andriole (2009) & $\mathrm{E}$ & $\begin{array}{l}\text { Literature review, survey (sample of more } \\
\text { than } 50 \text { CIOs and CTOs) and interviews }\end{array}$ & & $\mathrm{x}$ & \\
\hline $\begin{array}{l}\text { Bart and Turel } \\
(2010)\end{array}$ & $\mathrm{E}$ & $\begin{array}{l}\text { Survey (sample of } 94 \text { board members of } \\
\text { Canadian organizations) }\end{array}$ & $\mathrm{x}$ & $\mathrm{x}$ & \\
\hline $\begin{array}{l}\text { Benaroch and } \\
\text { Chernobai (2017) }\end{array}$ & $\mathrm{E}$ & $\begin{array}{l}\text { Event study methodology (sample of } 110 \\
\text { operational IT failures) }\end{array}$ & $\mathrm{x}$ & & \\
\hline $\begin{array}{l}\text { Best and Buckby } \\
(2007)\end{array}$ & $\mathrm{E}$ & $\begin{array}{l}\text { Literature review and survey to } 32 \text { industry } \\
\text { professionals to pilot test the model }\end{array}$ & & $\mathrm{x}$ & \\
\hline $\begin{array}{l}\text { Butler and Butler } \\
\text { (2010) }\end{array}$ & $\mathrm{C}$ & $\begin{array}{l}\text { Literature review, analysis of King III and } \\
\text { analysis of industry frameworks }\end{array}$ & & $\mathrm{x}$ & \\
\hline $\begin{array}{l}\text { Coertze and Von } \\
\text { Solms (2013) }\end{array}$ & $\mathrm{E}$ & $\begin{array}{l}\text { Qualitative content analysis of corporate } \\
\text { websites and integrated reports (sample of } 20 \\
\text { South African, } 18 \text { United Kingdom and } 19 \\
\text { American organizations) } \\
\end{array}$ & & $\mathrm{x}$ & \\
\hline $\begin{array}{l}\text { Coertze and von } \\
\text { Solms (2014) }\end{array}$ & $\mathrm{C}$ & Discussion paper & & $\mathrm{x}$ & \\
\hline $\begin{array}{l}\text { Héroux and Fortin } \\
\text { (2018) }\end{array}$ & $\mathrm{E}$ & Survey (sample of 66 senior executives) & & & $\mathrm{x}$ \\
\hline Higgs et al. (2016) & $\mathrm{E}$ & $\begin{array}{l}\text { Determinant and returns analysis of security } \\
\text { breach data (sample of } 49,924 \text { breaches for } \\
\text { RQ1 and } 390 \text { breaches for RQ2) }\end{array}$ & & & $\mathrm{x}$ \\
\hline $\begin{array}{l}\text { Jewer and McKay } \\
\text { (2012) }\end{array}$ & $\mathrm{E}$ & $\begin{array}{l}\text { Literature review, in-depth interviews with } 10 \\
\text { corporate directors and survey (sample of } 188 \\
\text { board members) }\end{array}$ & $\mathrm{x}$ & & $\mathrm{x}$ \\
\hline $\begin{array}{l}\text { Kambil and Lucas } \\
(2002)\end{array}$ & $\mathrm{E}$ & $\begin{array}{l}\text { Survey (sample of } 37 \text { CEOs) and board data } \\
\text { collected from various sources }\end{array}$ & $\mathrm{x}$ & & \\
\hline $\begin{array}{l}\text { Kritzinger-von } \\
\text { Solms and Strous } \\
(\mathbf{2 0 0 3 )}\end{array}$ & $\mathrm{E}$ & $\begin{array}{l}\text { Review of reference documents on corporate } \\
\text { governance and reference documents on } \\
\text { security management }\end{array}$ & $\mathrm{x}$ & & \\
\hline $\begin{array}{l}\text { Kuruzovich et al. } \\
\text { (2012) }\end{array}$ & $\mathrm{E}$ & Survey (sample of 256 directors) & $\mathrm{x}$ & $\mathrm{x}$ & \\
\hline Mähring (2006) & $\mathrm{C}$ & Literature review & $\mathrm{x}$ & $\mathrm{x}$ & \\
\hline $\begin{array}{l}\text { Mohamad et al. } \\
\text { (2014) }\end{array}$ & $\mathrm{E}$ & $\begin{array}{l}\text { Literature review and model testing based on } \\
\text { survey (sample of } 7 \text { CIOs) }\end{array}$ & & $\mathrm{x}$ & \\
\hline $\begin{array}{l}\text { Nolan and McFarlan } \\
(2005)\end{array}$ & $\mathrm{C}$ & Discussion paper & $\mathrm{x}$ & $\mathrm{x}$ & \\
\hline O'Donnell (2004) & $\mathrm{C}$ & Discussion paper & & & $\mathrm{x}$ \\
\hline $\begin{array}{l}\text { Oliver and Walker } \\
(2006)\end{array}$ & $\mathrm{C}$ & Hypothetical case study & & $\mathrm{x}$ & \\
\hline $\begin{array}{l}\text { Parent and Reich } \\
(2009)\end{array}$ & $\mathrm{E}$ & $\begin{array}{l}\text { Literature review and multiple case study (6 } \\
\text { organizations) }\end{array}$ & & $\mathrm{x}$ & \\
\hline $\begin{array}{l}\text { Posthumus and von } \\
\text { Solms (2008) }\end{array}$ & $\mathrm{C}$ & Discussion paper & $\mathrm{x}$ & $\mathrm{x}$ & \\
\hline $\begin{array}{l}\text { Posthumus et al. } \\
\text { (2010) }\end{array}$ & $\mathrm{C}$ & Discussion paper & & $\mathrm{x}$ & \\
\hline
\end{tabular}




\begin{tabular}{|c|c|c|c|c|c|}
\hline \multirow[b]{2}{*}{ Reference } & \multirow[b]{2}{*}{ 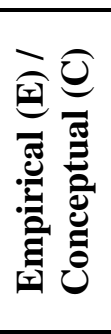 } & \multirow[b]{2}{*}{ Methodology } & \multicolumn{3}{|c|}{ Main subject } \\
\hline & & & 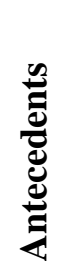 & 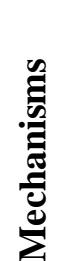 & 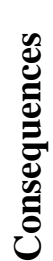 \\
\hline $\begin{array}{l}\text { Premuroso and } \\
\text { Bhattacharya (2007) }\end{array}$ & $\mathrm{E}$ & $\begin{array}{l}\text { Regression and discriminant analysis of data } \\
\text { on corporate governance, financial } \\
\text { performance and board technology } \\
\text { committees (sample of } 23 \text { firms) }\end{array}$ & $\mathrm{x}$ & & \\
\hline Raghupathi (2007) & $\mathrm{C}$ & Discussion paper & & & \\
\hline Read (2004) & $\mathrm{C}$ & Discussion paper & & $\mathrm{x}$ & \\
\hline $\begin{array}{l}\text { Trautman and } \\
\text { Altenbaumer-Price } \\
(\mathbf{2 0 1 0 )}\end{array}$ & $\mathrm{C}$ & $\begin{array}{l}\text { Review of academic literature, frameworks } \\
\text { and regulations }\end{array}$ & & $\mathrm{x}$ & \\
\hline Trites (2004) & $\mathrm{C}$ & Discussion paper & & $\mathrm{x}$ & \\
\hline $\begin{array}{l}\text { Turel and Bart } \\
\text { (2014) }\end{array}$ & $\mathrm{E}$ & $\begin{array}{l}\text { Survey (sample of } 171 \text { board members of } \\
\text { Canadian firms), content analysis of } \\
\text { responses and structured email-based } \\
\text { interviews }\end{array}$ & $\mathrm{x}$ & & $\mathrm{x}$ \\
\hline Turel et al. (2017) & $\mathrm{E}$ & $\begin{array}{l}\text { Survey (sample of } 98 \text { board members) for } \\
\text { study } 1 \text { and survey (sample of } 104 \text { board } \\
\text { members) for study } 2\end{array}$ & & & $\mathrm{x}$ \\
\hline $\begin{array}{l}\text { Valentine and } \\
\text { Stewart (2013a) }\end{array}$ & $\mathrm{E}$ & $\begin{array}{l}\text { Literature review, revelatory case study, } \\
\text { survey ( } 93 \text { responses) and content analysis of } \\
\text { online governance discussion forums }\end{array}$ & & $\mathrm{x}$ & \\
\hline $\begin{array}{l}\text { Valentine and } \\
\text { Stewart (2013b) }\end{array}$ & $\mathrm{C}$ & Literature review & $\mathrm{x}$ & $\mathrm{x}$ & \\
\hline $\begin{array}{l}\text { Valentine and } \\
\text { Stewart (2015) }\end{array}$ & $\mathrm{E}$ & $\begin{array}{l}\text { Literature review and survey (sample of } 177 \\
\text { chairmen/women, directors and experienced } \\
\text { IT and non-IT executives and consultants) }\end{array}$ & & $\mathrm{x}$ & \\
\hline Yayla and Hu (2014) & $\mathrm{E}$ & $\begin{array}{l}\text { Cross-sectional time series analyses of data } \\
\text { collected from various sources (sample of } 113 \\
\text { firms) }\end{array}$ & & & $\mathrm{x}$ \\
\hline
\end{tabular}

\section{Table 1 Final set of papers}

\section{RESEARCH FINDINGS}

In this section, the selected board level IT governance research papers were used to formulate answers to the research questions presented in the introduction.

\section{The antecedents of board level IT governance}

In order to create a better understanding of how to increase the level of board involvement in

IT governance, an answer to RQ1: "What are the antecedents of board level IT governance?" 
will be sought. Indeed, some researchers examined the antecedents of board level IT governance. An overview of the antecedents identified in the literature can be found in Table 2.

\begin{tabular}{|c|c|c|c|c|}
\hline & Antecedent & $\begin{array}{l}\text { Effect on } \\
\text { board } \\
\text { level ITG }\end{array}$ & Study & $\begin{array}{l}\text { Number } \\
\text { of } \\
\text { studies }\end{array}$ \\
\hline \multirow{11}{*}{ 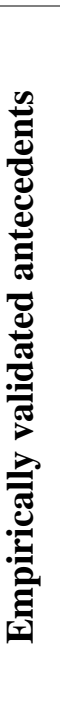 } & Proportion of insiders & Negative & Jewer and McKay (2012) & 1 \\
\hline & Board size & Negative & Jewer and McKay (2012) & 1 \\
\hline & IT competency & Positive & $\begin{array}{l}\text { Jewer and McKay (2012); Kambil and } \\
\text { Lucas (2002) }\end{array}$ & 2 \\
\hline & Organization age & Negative & Jewer and McKay (2012) & 1 \\
\hline & $\begin{array}{l}\text { Overall role of IT } \\
\text { (operational and/or } \\
\text { strategic reliance on IT) }\end{array}$ & Positive & Jewer and McKay (2012) & 1 \\
\hline & Need for new IT & Positive & Turel and Bart (2014) & 1 \\
\hline & Need for reliable IT & Positive & Turel and Bart (2014) & 1 \\
\hline & Strategic importance of IT & Positive & $\begin{array}{l}\text { Kuruzovich, Bassellier, } \quad \& \\
\text { Sambamurthy (2012) }\end{array}$ & 1 \\
\hline & IT intensity & Positive & Benaroch and Chernobai (2017) & 1 \\
\hline & Firm performance & Positive & $\begin{array}{l}\text { Benaroch and Chernobai (2017); } \\
\text { Premuroso and Bhattacharya (2007) }\end{array}$ & 2 \\
\hline & Corporate governance & Positive & Premuroso and Bhattacharya (2007) & 1 \\
\hline \multirow{7}{*}{ 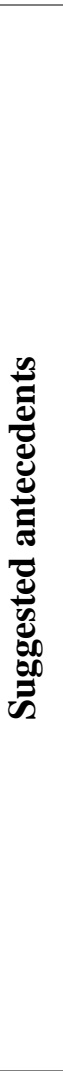 } & Lack of IT expertise & Negative & $\begin{array}{l}\text { Andriole (2009); Bart and Turel (2010); } \\
\text { Best and Buckby (2007); Coertze and } \\
\text { Von Solms (2013, 2014); Nolan and } \\
\text { McFarlan (2005); Parent and Reich } \\
\text { (2009); Turel and Bart (2014); } \\
\text { Valentine and Stewart (2013a, 2013b, } \\
\text { 2015); Yayla and Hu (2014) }\end{array}$ & 12 \\
\hline & Motivational factors & Negative & $\begin{array}{l}\text { Andriole (2009); Kritzinger-von Solms } \\
\text { and Strous (2003); Parent and Reich } \\
\text { (2009); Posthumus and von Solms } \\
\text { (2008); Valentine and Stewart (2013b) }\end{array}$ & 5 \\
\hline & Director age & Negative & $\begin{array}{l}\text { Andriole (2009); Mähring (2006); } \\
\text { Valentine and Stewart (2013b) }\end{array}$ & 3 \\
\hline & $\begin{array}{l}\text { Lack of understanding of } \\
\text { the role of IT in the } \\
\text { organization }\end{array}$ & Negative & $\begin{array}{l}\text { Posthumus and von Solms (2008); } \\
\text { Posthumus, von Solms, \& King (2010); } \\
\text { Valentine and Stewart (2013b); Yayla } \\
\text { and } \mathrm{Hu}(2014)\end{array}$ & 4 \\
\hline & $\begin{array}{l}\text { Lack of guidance on board } \\
\text { level IT governance }\end{array}$ & Negative & $\begin{array}{l}\text { Parent and Reich (2009); Posthumus } \\
\text { and von Solms (2008) }\end{array}$ & 2 \\
\hline & $\begin{array}{l}\text { Lack of IT information at } \\
\text { board level }\end{array}$ & Negative & $\begin{array}{l}\text { Oliver and Walker (2006); Posthumus } \\
\text { and von Solms (2008) }\end{array}$ & 2 \\
\hline & Guidance and regulations & Positive & $\begin{array}{l}\text { Bart and Turel (2010); Mähring (2006); } \\
\text { Trautman and Altenbaumer-Price } \\
(2010)\end{array}$ & 3 \\
\hline
\end{tabular}

Table 2 Antecedents of board level IT governance 
There are few studies that empirically investigate the influence of these factors on the level of board involvement in IT governance. An overview of these empirical studies and the identified antecedents is shown in the first part of Table 2. The factors that were found to have a certain impact on the degree of involvement of the board in IT governance are not limited to board attributes. Next to the proportion of insiders on the board, the size of the board and the IT competency among board members, organization characteristics such as the organization age, the role of IT in the organization (an operational or strategic reliance on IT), the need for new IT, the need for reliable IT, the strategic importance of IT, the IT intensity, firm performance and corporate governance are mentioned as antecedents of board level IT governance (Benaroch and Chernobai, 2017; Jewer and McKay, 2012; Kambil and Lucas, 2002; Kuruzovich, et al., 2012; Premuroso and Bhattacharya, 2007; Turel and Bart, 2014).

Surprisingly, while the researchers were expecting to find a positive relationship between the proportion of insiders on the board and the level of its involvement in IT governance, this relationship proved to be negative. This uncertainty about the effect of the proportion of insiders is also present in corporate governance research. As no clear argument could be found to explain this negative effect, this relationship is in need of further research. (Jewer and McKay, 2012)

The size of the board appears to be negatively related to the involvement of the board in IT governance. Jewer and McKay (2012) suggest that smaller boards might be able to collaborate more effectively. However, the exact reason behind this negative relationship was not yet examined thoroughly.

The positive effect of the IT competency on board level IT governance confirms the studies that promote the development of IT expertise at board level. Kambil and Lucas (2002) demonstrate that the number of internal and external board members who worked in IT is 
positively correlated with the frequency with which the board of directors reviews IT plans and performance. Jewer and McKay (2012) discuss the positive effect of the board IT competency as well. However, it is important to note that these authors define the board IT competency as the combination of the IT expertise at board level and the IT governance mechanisms the board uses to govern IT. This means that according to this study, the level of board involvement is positively correlated with both the IT expertise of board members and the presence of board level IT governance structures, processes and relational mechanisms, which will be discussed in the next section.

A negative relationship was found between the age of the organization and board IT governance. This finding is in accordance with previous studies that suggest that organizations align their practices with those common at the time of founding (Eisenhardt, 1988; Stinchcombe and March, 1965; Tolbert and Zucker, 1983). As organizations tend to be resistant to change, these practices are likely to persist. This results in boards that are less involved in IT governance of organizations that were founded in a time when IT was not as pervasive as it is today.

The antecedent that has received the most attention is the role of IT in the organization. The strategic impact grid created by Nolan and McFarlan (2005) is the most frequently used framework by board level IT governance researchers to define this role of IT (Bart and Turel, 2010; Parent and Reich, 2009; Posthumus, et al., 2010; Turel and Bart, 2014). The authors define the role of IT in an organization by considering two strategic issues. On the one hand, they consider defensive IT which focusses on operational reliability, ensuring smoothly running, secure, cost-effective IT systems. On the other hand, some organizations consider IT as a strategic asset, enabling them to offer new products and services or to be more responsive to customer needs. This is called offensive IT. Hence, two technology dimensions are considered by the authors: the organization's need for reliable IT and its need for new IT. This 
results in a matrix with four modes: support mode, factory mode, turnaround mode and strategic mode, called the strategic impact grid. Organizations in support mode only need technology to support employee's activities. Factory mode organizations require highly reliable IT, but have a low need for new IT. When the need for new IT is high, but the organization does not rely on IT for the continuity of the business, turnaround mode applies. Organizations with a high need for both reliable and new IT are situated in the strategic mode. According to the authors, the degree and nature of the involvement of the board of directors in IT governance should depend on the position of the organization in the strategic impact grid.

Other studies examining the influence of the role of IT in the organization on the level of involvement of the board in IT governance, define this role of IT somewhat differently. Jewer and McKay (2012) consider an organization's operational or strategic reliance on IT. From their operationalization of these constructs, it can be concluded that operational reliance on IT relates to the need for reliable IT from the strategic impact grid, while strategic reliance on IT relates to the need for new IT. Benaroch and Chernobai (2017) consider the IT intensity of the firm and argue this parallels the role of IT as defined by Jewer and McKay (2012). The IT intensity is measured as the industry level IT intensity based on the share of IT capital in total capital for an industry segment, weighted by the percentage of the firm's sales within that segment. Kuruzovich, et al. (2012) refer to the strategic importance of IT, which is described as "the degree to which IT has the potential to have a transformational impact on the associated business of the organization". Hence, they mainly focus on the need for new IT. All studies confirm that the role of IT is related to board IT governance. Figure 3 shows a summary of the different perspectives on the role of IT in an organization as well as an overview of board level IT governance studies based on the strategic impact grid, indicating its popularity and application potential. These studies will be discussed in the following sections of this paper. 


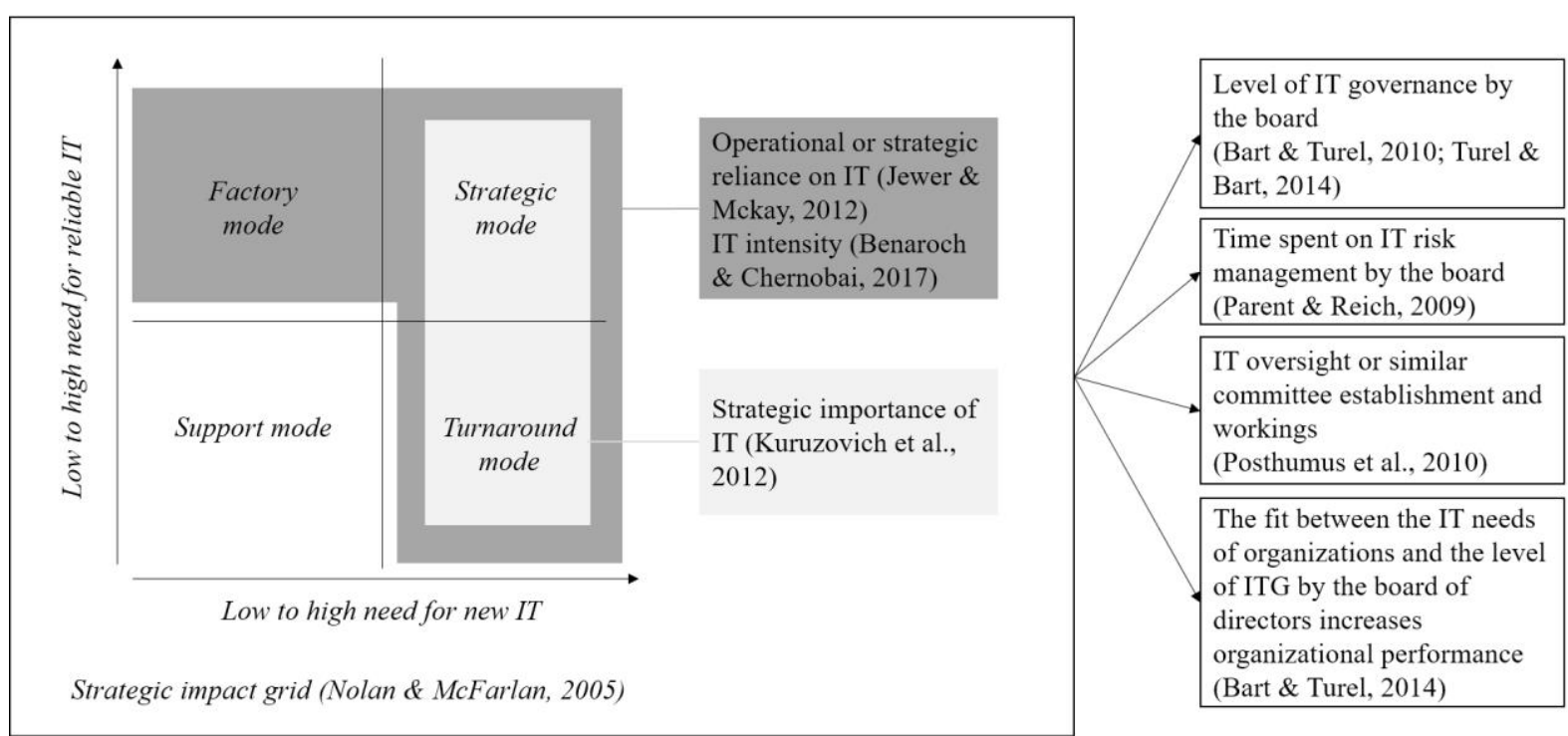

Figure 3 Role of IT as antecedent of board level IT governance - an overview

Premuroso and Bhattacharya (2007) applied a different perspective and examined the link between corporate governance and the establishment of board level technology committees. Due to the link between IT governance and corporate governance (De Haes and Van Grembergen, 2015), it is not surprising that corporate governance is significantly and positively associated with the decision to establish a technology committee at board level.

The overall performance of the organization appears to have an impact on the level of involvement of the board in IT governance. That is, Premuroso and Bhattacharya (2007) found that firms with higher returns on assets, returns on equity and net profit margins are more likely to form a board level technology committee than others. Yet, Benaroch and Chernobai (2017) reported a somewhat contradicting result. They found that after an operational IT failure, improvements are made to the implementation of board level IT governance and that these improvements are proportional to the degree of negative market reaction to the IT failure. This means that lower financial performance induces firms to change their board level IT governance mechanisms. This seemingly contradicting result might be explained by the fact that while Premuroso and Bhattacharya (2007) focus on the establishment of board level technology committees, Benaroch and Chernobai (2017) take a broader view on board level IT 
governance and examine the changes in directors' IT capital, the chief information officer (CIO) or chief technology officer (CTO) on the board and board IT committees. Furthermore, they specifically note that only a very small subsample of organizations installed a board level IT committee in the period that was examined. As a consequence, they were unable to perform the analysis for the change in this variable. Lastly, the study of Benaroch and Chernobai (2017) focused on the reaction to a specific event, i.e. operational IT failure and the associated change in firm market value, while Premuroso and Bhattacharya (2007) examined firm performance, regardless of any specific events.

Next to the limited number of studies that empirically confirmed the influence of certain factors on board IT governance, other researchers mention factors that could enable or inhibit the board to be involved in IT governance. An overview of these factors can be found in the second part of Table 2 .

Some researchers argue that boards are not as involved in IT governance as they should be, because they just do not know how to exercise this involvement. They state that the lack of guidance on board level IT governance inhibits boards to properly govern IT (Coertze and von Solms, 2014; Parent and Reich, 2009; Posthumus and von Solms, 2008). Indeed, others mention guidance and regulations as a way to increase the level of board IT governance (Bart and Turel, 2010; Mähring, 2006; Trautman and Altenbaumer-Price, 2010). The knowledge and information that boards have seem to hold them back as well. Their lack of understanding of the role of IT in the organization and the lack of IT information that reaches the board were mentioned as inhibitors (Oliver and Walker, 2006; Posthumus and von Solms, 2008; Posthumus, et al., 2010; Valentine and Stewart, 2013b; Yayla and Hu, 2014).

In accordance with the previously mentioned studies many authors point to the lack of IT expertise as an inhibitor of board involvement in governing IT (Andriole, 2009; Bart and Turel, 
2010; Best and Buckby, 2007; Coertze and Von Solms, 2013, 2014; Nolan and McFarlan, 2005; Parent and Reich, 2009; Turel and Bart, 2014; Valentine and Stewart, 2013a, 2013b, 2015; Yayla and $\mathrm{Hu}, 2014)$. The often higher age of directors is also put forward as an inhibitor, as this might be associated with a lower understanding of technology (Andriole, 2009; Mähring, 2006; Valentine and Stewart, 2013b).

Some antecedents were only mentioned by one study which does not provide any validation. Yet, in light of providing an exhaustive overview and reaching our goal of advancing this research topic, these factors are worth mentioning. A few authors refer to more operational, non-board practices as antecedents of board level IT governance. First, the CIO reporting to the chief operating officer (COO) or chief financial officer (CFO) instead of the CEO was mentioned to have a negative impact on board level IT governance, as it might induce communication to the board in which IT is portrayed as an operational rather than a strategic asset (Valentine and Stewart, 2013b). Second, the existence of non-board IT governance practices could be positively correlated with board involvement, as board practices are reflected in the organization. Such non-board IT governance practices are those practices that are established at a lower level in the organization than that of the board of directors, such as an IT steering committee at business unit level. However, in case these non-board practices are highly effective, the need for board involvement in IT governance might decrease, resulting in a negative correlation (Mähring, 2006). Other antecedents mentioned are the lack of understanding of how to implement board level IT governance (Coertze and von Solms, 2014), compensation mechanisms for both board members and CEOs (Bart and Turel, 2010), trends that portray IT as having strategic importance (Mähring, 2006) and the overall board effectiveness (Mähring, 2006).

In conclusion many board attributes, organization characteristics and contextual factors are mentioned as having an influence on the level of board IT governance. However, little 
empirical research has yet been conducted that confirms these propositions and little is known about how exactly these factors bring about an increase or decrease in board involvement.

\section{Board level IT governance practices}

The majority of papers on board level IT governance discusses possible approaches to implement board involvement in IT governance. This section contains an overview of these approaches, thereby answering RQ2: "Which processes, structures and relational mechanisms can be used to implement board level IT governance?". As explained in the section on the key concepts of this paper, IT governance can be deployed using a mixture of structures, processes and relational mechanisms (De Haes and Van Grembergen, 2015). Accordingly, possible approaches were classified into these three categories. An overview of the practices mentioned in the board level IT governance literature is shown in Table 3.

\begin{tabular}{|c|c|c|}
\hline \multicolumn{2}{|c|}{ Board level IT governance practices } & \multirow[b]{2}{*}{$\begin{array}{l}\text { Number } \\
\text { of studies }\end{array}$} \\
\hline Practice & Study & \\
\hline \multicolumn{2}{|l|}{ Structures } & 15 \\
\hline $\begin{array}{l}\text { IT oversight or similar } \\
\text { committee at the level of the } \\
\text { board }\end{array}$ & $\begin{array}{l}\text { Coertze and von Solms (2014); Higgs, et al. (2016); } \\
\text { Nolan and McFarlan (2005); Oliver and Walker } \\
\text { (2006); Posthumus, et al. (2010); (Premuroso and } \\
\text { Bhattacharya, 2007); Read (2004); Turel and Bart } \\
\text { (2014) }\end{array}$ & 8 \\
\hline IT expertise at the board & $\begin{array}{l}\text { Mohamad, Hendrick, O’Leary, \& } \\
\text { Valentine and Stewart }(2013 \mathrm{a}, 2015)\end{array}$ & 3 \\
\hline CIO part of the (executive) board & Coertze and von Solms (2014); Posthumus, et al. (2010) & 2 \\
\hline CIO reporting to the $\mathrm{CEO}$ & Valentine and Stewart (2013b) & 1 \\
\hline \multicolumn{2}{|l|}{ Processes } & 3 \\
\hline Asking IT-related questions & $\begin{array}{l}\text { Bart and Turel (2010); Nolan and McFarlan (2005); } \\
\text { Turel and Bart (2014) }\end{array}$ & 3 \\
\hline \multicolumn{2}{|l|}{ Relational mechanisms } & 5 \\
\hline $\begin{array}{l}\text { Effective communication about } \\
\text { IT from and to the board }\end{array}$ & $\begin{array}{l}\text { Andriole (2009); Coertze and von Solms (2014); } \\
\text { Kuruzovich, et al. (2012); Oliver and Walker (2006); } \\
\text { Yayla and } \mathrm{Hu} \text { (2014) }\end{array}$ & 5 \\
\hline $\begin{array}{l}\text { CIO regularly meeting with the } \\
\text { board }\end{array}$ & Butler and Butler (2010); Kuruzovich, et al. (2012) & 2 \\
\hline
\end{tabular}

Table 3 Overview of board level IT governance structures, processes and relational 


\section{Structures}

From Table 3 it is clear that structures at the level of the board to operationalize their engagement in IT governance are widely examined. The structures we found in literature are: an IT oversight or similar committee at the level of the board (Coertze and von Solms, 2014; Nolan and McFarlan, 2005; Oliver and Walker, 2006; Posthumus, et al., 2010; Read, 2004; Turel and Bart, 2014), IT expertise at the board (Mohamad, et al., 2014; Valentine and Stewart, 2013a, 2015), the CIO being part of the (executive) board (Coertze and von Solms, 2014; Posthumus, et al., 2010) and the CIO reporting to the CEO (Valentine and Stewart, 2013b).

\section{IT oversight or similar committee}

The most frequently mentioned approach to increase board involvement in IT governance is the establishment of an IT oversight or similar committee at board level (Coertze and von Solms, 2014; Higgs, et al., 2016; Nolan and McFarlan, 2005; Oliver and Walker, 2006; Posthumus, et al., 2010; Premuroso and Bhattacharya, 2007; Read, 2004; Turel and Bart, 2014). Different terms are used to refer to such a committee; IT oversight committee (Coertze and von Solms, 2014; Nolan and McFarlan, 2005; Posthumus, et al., 2010), IT governance committee (Nolan and McFarlan, 2005; Oliver and Walker, 2006), IT steering committee (Read, 2004), IT committee (Benaroch and Chernobai, 2017; Turel and Bart, 2014) and board-level technology committee (Higgs, et al., 2016; Premuroso and Bhattacharya, 2007). According to Nolan and McFarlan (2005), such a committee should assist the board in keeping an eye out for what competitors and other organizations are doing with technology. On the other hand, Oliver and Walker's research (2006) focuses on software development projects and describes the role of the IT governance committee as a body responsible for governing: "expenditure and realization of benefits of current and future IT investments", "standards, risk and compliance" and "performance". 
Posthumus, et al. (2010) argue that the IT oversight committee should ensure that "IT is a standard topic on the board's agenda to be addressed through a structured approach". Moreover, the committee is responsible for making sure that the board possesses all information necessary for IT-related decision-making. Higgs, et al. (2016) focus on risk and posit that the committee should be actively involved in identifying, mitigating and reporting on IT-related risks.

Currently, corporate governance guidelines do not include the establishment of an IT oversight committee (Premuroso and Bhattacharya, 2007). This could be an advantage for firms that do opt for the voluntary establishment of such a committee. That is, the firstmover advantage (Premuroso and Bhattacharya, 2007) and signaling theory (Higgs, et al., 2016) could be applied to the formation of an IT oversight committee, as it demonstrates the firm's superior IT governance and signals the importance it attaches to IT-related matters.

Despite the advice of these studies to establish a board level IT oversight or similar committee, research points out that the occurrence of these committees in practice remains an exception (Andriole, 2009; Coertze and Von Solms, 2013; Héroux and Fortin, 2018; Jewer and McKay, 2012). Figures range from 74.5\% (Andriole, 2009) to 78.8\% (Héroux and Fortin, 2018) and 91\% (Jewer and McKay, 2012) of respondents that indicate not having such a committee. Benaroch and Chernobai (2017) report that around $17 \%$ of the firms in their sample have a board level IT committee. Moreover, interviews with practitioners (Andriole, 2009; Jewer and McKay, 2012) reveal that some of them are not at all in favor of introducing such a committee, because of time constraints or the perception that they do not have the appropriate expertise. Indeed, Higgs, et al. (2016) stress that establishing a board level technology committee is costly as it requires board member time, additional compensation, additional reporting and could be a risky endeavor 
in terms of reputation and capital if risks materialize on the committee's watch. Therefore, the authors argue that boards might hesitate to establish such a committee if they feel they do not possess the appropriate level of IT expertise. Coertze and Von Solms (2013) warn for the pitfalls of establishing a committee at board level as well. They stress that even though a committee is established, the board still remains accountable.

Indeed, not all types of organizations should implement an IT oversight or similar committee. The need for such a committee depends on the role of IT in the organization (Coertze and von Solms, 2014; Nolan and McFarlan, 2005; Posthumus, et al., 2010). Coertze and von Solms (2014) build on the notion of a defensive and offensive IT strategy as described by Nolan and McFarlan (2005), however, use a slightly different definition. They posit that organizations can be placed on an IT alignment continuum, ranging from a defensive stance where IT supports the business to an offensive stance where IT is the business. Researchers agree that an offensive IT strategy or stance requires a separate IT oversight or similar committee (Coertze and von Solms, 2014; Nolan and McFarlan, 2005; Posthumus, et al., 2010). The audit committee or risk management committee can take up the responsibility of IT governance at board level in organizations with a defensive IT strategy or stance (Nolan and McFarlan, 2005; Posthumus, et al., 2010). Another factor influencing the need of an IT oversight committee is the IT expertise within the board. Boards with a limited level of IT expertise might benefit more from establishing an IT oversight or similar committee than those with significant IT expertise (Coertze and von Solms, 2014).

When organizations do opt for the implementation of an IT oversight or similar committee, the board should appoint its members and chairman, define its ties with the audit committee and create a committee charter. Appropriate members are independent directors, similar to other board-level committees like the audit or compensation committee. Moreover, at least one IT 
expert with profound knowledge of the business needs should be included as a member. Depending on the role of IT in the organization, the chairman should be an IT-savvy business executive or an IT expert. Furthermore, the IT oversight committee should have a close relationship with the audit committee by for example including the same person in both committees. (Nolan and McFarlan, 2005)

In practice, IT oversight or similar committees at the level of the board of directors appear to have a rather specific scope. The board level IT committees identified by Benaroch and Chernobai (2017) in their sample included: IT steering committees which monitor the overall IT performance and the governance of IT resources, IS audit committees, which are often a subcommittee of the audit committee and monitor IT controls and IT risk management processes, information security committees and technology and operational risk committees.

Posthumus, et al. (2010) specify the frequency with which the board level committee responsible for IT governance should report to the board. As explained earlier, the audit committee should take on this task in organizations in a defensive mode. More specifically, in organizations in support mode, the audit committee should report to the board every 6 to 12 months, while the factory mode requires a report every 3 to 6 months. The IT oversight or similar committee in organizations in an offensive mode should report to the board every 3 months.

\section{IT expertise at board level}

Several researchers argue that the IT expertise of directors is a crucial element of the board's involvement in governing IT (Mohamad, et al., 2014; Valentine and Stewart, 2013a, 2015). Such expertise is needed to adequately monitor management. That is, it is the board's task to determine whether management has established IT governance procedures, such as policies to ensure IT security and succession plans for key IT personnel, and whether these procedures are 
appropriate (Trites, 2004). In order to evaluate the appropriateness of the procedures, directors have to possess the right competencies (Benaroch and Chernobai, 2017; Trites, 2004; Valentine and Stewart, 2015). In addition, the IT expertise of board members is important for supporting strategic IT-related initiatives, as it can be viewed as a cognitive bias that influences strategic decisions. Similarly, a lack of such expertise could inhibit innovation (Héroux and Fortin, 2018). The value of IT expertise of independent and dependent directors is slightly different. While independent directors with IT expertise enable the board to provide advice to management, to facilitate access to external IT parties, to attract qualified IT management and to advocate for more IT budgets, internal directors with IT expertise are important to make sure the board understands the business costs of IT risks, enable the swift allocation of resources and facilitate priority setting to adjust IT weaknesses (Benaroch and Chernobai, 2017).

Research confirms that there is little IT expertise or experience in the boardroom. Valentine and Stewart (2013a) found that only $36.47 \%$ of the respondent organizations had one or more board members with board level IT governance knowledge, skills and experience. In the sample of Héroux and Fortin (2018), on average 5.5\% of the board's members had IT-related functional expertise. Andriole (2009) reports that $62.7 \%$ of the organizations in his sample do not consider IT experience to be a requirement to become a member of the board. The study of Coertze and Von Solms (2013) confirms these findings. They argue that even though an increasing number of organizations pursue board members with IT expertise or experience, the number of board members with IT competencies remains relatively low. Nevertheless, board members acknowledge the importance of having IT expertise or experience at this level. $74.42 \%$ of the respondents in the survey of Valentine and Stewart (2013a) confirm the importance of including board members with IT governance knowledge, skills and experience. An interesting observation is the fact that when organizations do take action to increase the IT 
expertise at board level, this is dominated by an increase in the ratio of internal directors with IT capital as opposed to independent directors (Benaroch and Chernobai, 2017).

In order to gain a better understanding of the IT competencies needed at the level of the board to adequately perform their IT oversight role, Valentine and Stewart (2013a, 2015) created a set of director competencies. They suggest three main competencies: "direct and govern technology-enabled strategy and planning to maximize the advantages of technology and enhance performance at all levels of the organization", "lead and govern business technology investment and risk" and "direct and govern technology-enabled innovation and value creation" (Valentine and Stewart, 2015). An important nuance in these competencies is that boards should understand how management should handle technology, and should not be aware of all technology details (Valentine and Stewart, 2013a). Similarly, Mohamad, et al. (2014) developed a model to evaluate the IT competencies at board level. In accordance with the work of Trites (2004), 33 competencies were identified and classified into 4 categories: strategic planning issues, internal control issues, business risk issues and privacy and legal issues. However, it should be noted that Mohamad, et al. (2014) validated their model using a survey for which they received only 7 responses. That is why this research is clearly in need of additional validation.

\section{$C I O$ reporting to the $C E O$}

Some authors consider the position of the CIO when discussing board level IT governance. Valentine and Stewart (2013b) argue that the CIO should report to the CEO. This is the most commonly used structure according to the research of Andriole (2009), who found that $49 \%$ of their respondents implemented a structure where the $\mathrm{CIO}$ reports to the CEO. However, there are still CIOs reporting to the CFO or COO, respectively $23.5 \%$ and $13.7 \%$ (Andriole, 2009). Valentine and Stewart (2013b) advise against these kind of structures as it influences the information that reaches the board. That is to say, CFOs and COOs tend to have more "reactive 
and backward-looking" rather than "strategic and forward-looking" key performance indicators (KPIs). This might cause them to look at IT as a cost, not a strategic asset, potentially affecting their communication about IT to the board (Valentine and Stewart, 2013b).

\section{CIO part of the (executive) board}

Others go one step further and suggest the CIO should be included as a member of the executive board. Benaroch and Chernobai (2017) argue that on the one hand, the CIO can provide the board with important information on IT matters of the organization. On the other hand, they play a pivotal role in implementing controls over IT resources in practice. Furthermore, the authors state that including the CIO in the executive board allows him to have more authority and contribution to the involvement of the board in IT governance. Coertze and von Solms (2014) argue that the CIO should be on the board of directors in organizations in an offensive stance. Posthumus, et al. (2010) are slightly more careful about the subject, however, they suggest that including the $\mathrm{CIO}$ on the board might be desirable as he has extensive knowledge about IT risk.

Coertze and Von Solms (2013) examined boards of directors in South Africa, the United Kingdom and the United States of America and concluded that the presence of the CIO in the board is rather an exception. Their results range from $10 \%$ of the organizations in South Africa having the $\mathrm{CIO}$ on the board to $16 \%$ in the United States of America. However, the study of Benaroch and Chernobai (2017) report that $72 \%$ of the firms in their sample have a CIO or CTO on the board of directors. A possible explanation for the enormous difference in these two research results is the fact that the latter study only included financial services firms in its sample, for which IT is at the core of the business (Sohal and Fitzpatrick, 2002), while the study by Coertze and Von Solms (2013) included firms of different sectors, including less IT intensive ones such as the oil and food and beverages sector. These results suggest that the role 
of IT in the organization might have an impact on the decision to include the CIO in the executive board.

\section{Processes}

Little research is available on board level IT governance processes. One example of a process that enables board engagement in IT governance was found, that is, boards of directors should ask themselves and management the right IT-related questions as part of their control and advise responsibilities (Bart and Turel, 2010; Nolan and McFarlan, 2005; Turel and Bart, 2014).

In order to provide guidance to boards on which IT-related questions they should get answers to, different question sets were created. First, Nolan and McFarlan (2005) created three sets of questions that boards should ask, depending on the organization's position in the strategic impact grid. The key themes that can be identified from these questions correspond to the five IT governance focus areas, as determined by the IT Governance Institute (ITGI) (2003): strategic alignment, value delivery, resource management, risk management and performance measurement.

Another question set was created by the Canadian Institute for Chartered Accountants (CICA) (2004) in their brochure called 20 Questions Directors Should Ask About IT. A second edition of this brochure was launched 8 years later by the CICA (2012). The questions are created around three key issues that should be addressed by the board: (1) the responsibilities of the board with regard to IT governance, (2) the organization's IT strategy and its appropriateness to deliver value to the organization and (3) performance and risk management. One additional question was identified that does not belong to these key issues, but addresses the board's use of information and information systems. Although both the Nolan and McFarlan and the CICA question sets cover similar themes such as strategy, value delivery, resource management and 
risk management, the latter deals with some additional themes, encouraging boards to consider their responsibilities with regard to IT governance. Although the CICA recognizes that the answers to these questions will vary across different types of organizations, they did not create separate sets applicable for certain organization types. Contrary to Nolan and McFarlan, only one general question set was created.

After the creation of these questions, Bart and Turel (2010) investigated which IT-related questions are actually raised in the boardroom. They based their research on the IT governance question set created by the CICA (2004). The degree to which each question was asked was examined. The authors found that boards generally do not adhere to the guidance provided by the CICA. On average, only 12 (out of the 20) questions are raised by board members. Furthermore, only $52 \%$ of the questions proposed are asked by the majority of the respondents. The level of importance attached to each question by board members was analyzed as well. For nearly all questions, the attached importance is not reflected in the frequency of mention, indicating that board members are indeed in need of more guidance on which questions to ask. The results show that the questions concerning IT risk are raised most frequently and are considered the most important by the respondents. This research also (partly) provides support to the claim of Nolan and McFarlan (2005) that different questions should be asked by board members in different types of organizations, as both the average number of questions asked and the importance attached to them varied significantly among the four IT modes. However, no significant associations were found with the factory mode, raising some doubts about the classification described by Nolan and McFarlan (2005).

\section{Relational mechanisms}

Similarly to processes, little academic research is attributed to relational mechanisms that could enable board level IT governance. A mechanism that is mentioned by several authors as being 
essential for boards to become involved in IT-related strategic decision making and control is effective communication about IT from and to the board (Andriole, 2009; Coertze and von Solms, 2014; Kuruzovich, et al., 2012; Oliver and Walker, 2006; Yayla and Hu, 2014). Additionally, researchers suggest that the CIO should regularly meet with the board (Butler and Butler, 2010; Kuruzovich, et al., 2012).

\section{Effective communication about IT from and to the board}

Coertze and von Solms (2014) discuss the way boards should communicate to the IT organization. The strategic impact grid of Nolan and McFarlan (2005) is applied again. The authors suggest that boards in a defensive stance have limited IT expertise and should therefore communicate the strategy they conceived to the IT organization in business terms, implying that the $\mathrm{CIO}$ is in charge of translating this strategy into IT objectives. On the other hand, boards in an offensive stance do have considerable IT expertise and are able to translate the business strategy into IT terms themselves, resulting in IT-oriented board directives.

Other authors address the topic of the communication from the organization to the board. It is suggested that it is the responsibility of the CIO to effectively communicate with the board on IT (Andriole, 2009; Yayla and Hu, 2014). Kuruzovich, et al. (2012) argue that the quality of IT-related information that reaches the board contributes to their decisionmaking. They define information exchange quality as "the extent to which processes allow the board to gain access to information about IT that is sufficient and relevant for their discussion of IT at board meetings". Their results show that the information exchange quality depends on the strategic importance of IT and that it contributes to IT alignment. Oliver and Walker (2006) conducted a study on software development reporting to managers and the board. As software development projects can have a substantial impact on the organization, the authors highlight the importance of reporting to the top echelons 
of the organization on these matters. They suggest 6 different reports: a financial report, a non-financial measures of progress report, a milestone report, an unfavorable events report, a risk report and a benefits realization schedule. One could argue that the board has a certain responsibility in ensuring effective communication from the organization to the board. Asking the right questions, as proposed in the previous section, might enable boards to make sure that the required information reaches the board.

\section{CIO regularly meeting with the board}

The CIO should be able to access the board and frequently meet with them (Butler and Butler, 2010). Kuruzovich, et al. (2012) argue that structures and attitudes at the top level of the organization might influence the capabilities of the CIO to communicate with them. They found a positive association between the strategic importance of IT and CIO communication capabilities. In addition, their results show that CIO communication with the board is positively associated with IT alignment.

\section{Consequences of board level IT governance}

The rationale for the need for board level IT governance is clear. However, few studies report on the consequences of involving the board in IT governance, proving the advantages of board level IT governance.

Higher levels of board level IT governance lead to increased organizational performance (Turel and Bart, 2014; Turel, Liu, \& Bart, 2017). Jewer and McKay (2012) showed that more board involvement in IT governance leads to a higher contribution of IT to firm performance. A slightly more specific view is provided by Yayla and $\mathrm{Hu}$ (2014), who demonstrate that the IT awareness, defined as "the extent to which the board is conscious of IT as a business function and able to formulate appropriate conceptions of what IT entails to their firm and industry" has a positive effect on firm performance. 
In the previous section, it was explained that the contingency approach, as adopted by Nolan and McFarlan (2005), might be legitimate as the topics raised in the boardroom vary among different types of organizations (Bart and Turel, 2010; Turel and Bart, 2014). However, when examining the consequences of involving the board in IT governance, contradictory results are presented. On the one hand, the study by Turel and Bart (2014) shows that regardless of the role of IT in the organization, increased board level IT governance leads to increased organizational performance. On the other hand, the study of the effect of IT awareness of the board on firm performance shows mixed results (Yayla and $\mathrm{Hu}, 2014$ ). The interaction effect between board IT awareness and IT intensity on firm performance is found to be insignificant in the aggregated sample. However, the results also show that, indeed, board IT awareness significantly increases firm performance and that this effect is considerably larger in high ITintensity industries. To conclude, the effect of the role of IT in the organization on the consequences of board level IT governance should be investigated further.

Instead of focusing on financial indicators, Héroux and Fortin (2018) concentrate on the effect of IT competence at board level on innovation. Against the authors' expectations, board IT competence was found to have no significant impact on innovation. Yet, the authors acknowledge that the IT competence of the board of directors in their sample was quite low (with an average of 5.5\% and a median of $0 \%$ of directors on the board having IT competence), possibly inhibiting a significant association.

Another focus is provided by Higgs, et al. (2016), who analyzed the link between board level technology committees and reported security breaches. As opposed to what one might expect, they found that initially, organizations with a technology committee at the level of the board are more likely to have reported breaches in a given year than those without such a committee. However, as these committees mature, the organization is less likely to be breached. An explanation for this somewhat surprising result is that organizations without a board level 
technology committee might not even detect or report security breaches. Young committees might increase the detection and reporting rate, while more established committees might also prevent security breaches. The market reaction to reported breaches also supports the establishment of a technology committee. That is, the negative market reaction to reported security breaches is mitigated by the presence of a technology committee. This leads the authors to believe that the presence of such a committee is positively perceived by the market when evaluating the information received on a reported breach.

Some researchers attempted to identify possible moderators and mediators of the relationship between board level IT governance and its outcomes. One of these factors is business/IT alignment (Héroux and Fortin, 2018; Kuruzovich, et al., 2012; Turel, et al., 2017). Turel, et al. (2017) take a specific focus on strategic alignment, which is found to be a partial mediator between board level IT governance and organizational performance. Interestingly, research shows that the effect of board level IT governance on firm performance has a similar magnitude as the effect of strategic alignment on firm performance (Turel, et al., 2017). This is a remarkable observation as ample research is available on attaining strategic alignment, while the domain of board level IT governance is far less developed. Considering the significance of the effect of board involvement in IT governance on firm performance as compared to strategic alignment, this research domain deserves much more attention than it currently receives. Héroux and Fortin (2018) hypothesized business/IT alignment to be a moderator of the relationship between board IT competence and innovation. Yet, their results did not support this hypothesis. Another moderator put forward in board level IT governance research is governance style. Indeed, authoritarian governance style is a moderator on the effect of board level IT governance on firm performance (Turel, et al., 2017). That is, organizations with boards adopting an authoritarian governance style exhibit lower firm performance. In fact, adopting a strong authoritarian governance style can even almost entirely remove the effect of 
board level IT governance on firm performance. This means that even though the board is engaged in IT governance, the style with which they interact with the executive management could suppress the positive effects.

\section{GAPS IN RESEARCH AND RESEARCH AGENDA}

Little research is available on the emerging topic of board level IT governance, forcing us to include a limited set of articles in this scoping review. Thus, the guidance of Webster and Watson (2002) on literature reviews is applied, who state that in case of an emerging issue authors can contribute by providing theoretical foundations through the development of a conceptual model. A conceptual model (Figure 4) is created that summarizes the existing research and that is used as a frame to develop an agenda for future research. Indeed, several gaps in academic research addressing the role of the board in IT governance can be identified from the conceptual model. These gaps introduce opportunities for future research in this field. In this section, the identified gaps are presented and a resulting research agenda is proposed. Gaps were identified in the three areas that are addressed by the research questions in this review. 


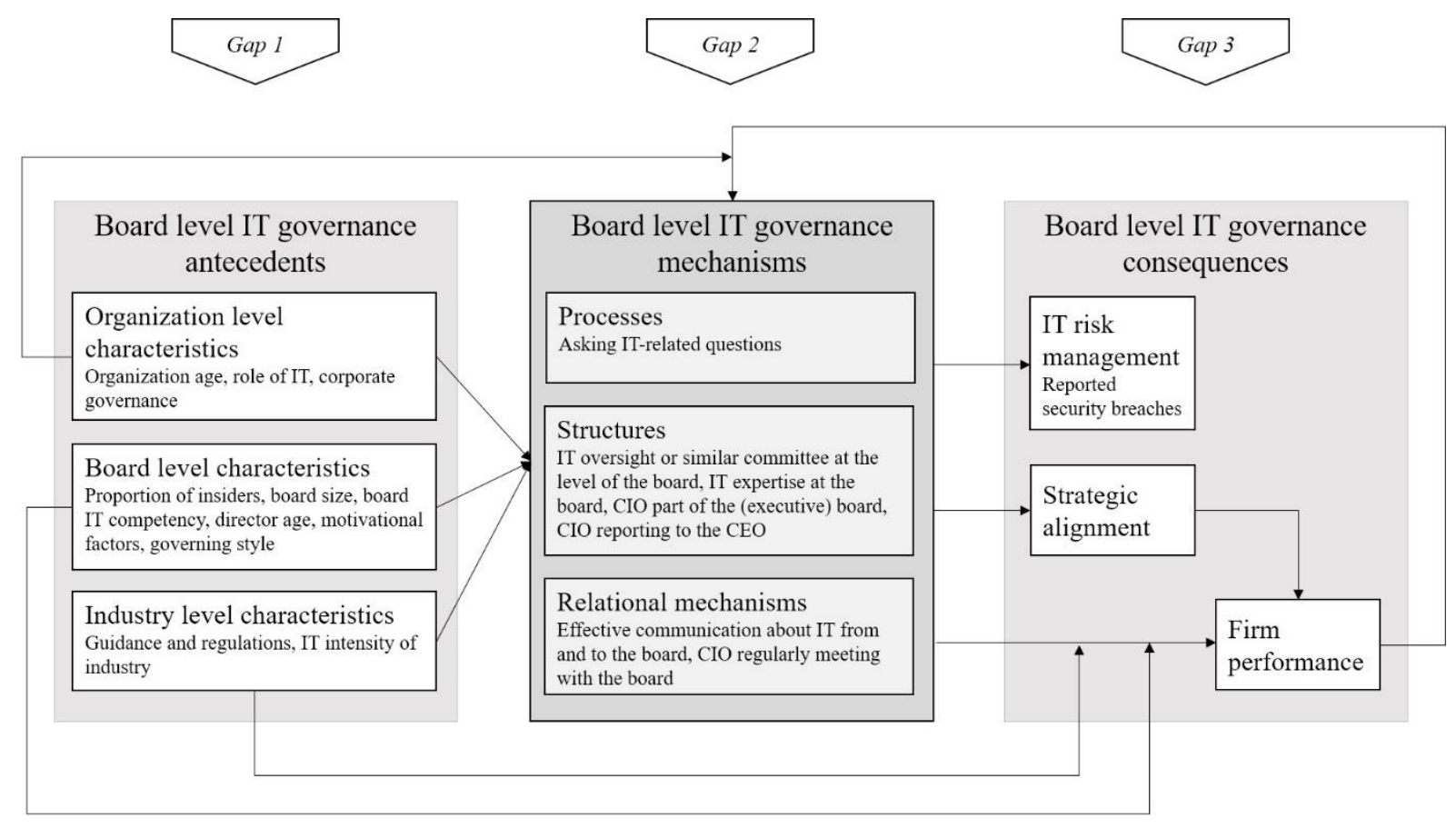

Figure 4 Conceptual model

\section{Gap 1: uncertainty about contingency factors}

Contingency theories state that an organization's success is dependent on various internal and external factors (Tosi Jr and Slocum Jr, 1984). Similarly, there is no one best way to shape board level IT governance practices. Indeed, researchers seem to agree that the most effective way to implement IT governance practices at the level of the board depends on various factors. Yet, ambiguity exists about what these influential factors are.

Despite the popularity of the strategic impact grid created by Nolan and McFarlan (2005), some studies showed results that do not support this classification. That is, no correlations were found between the level of engagement of the board in IT governance and the factory mode (Bart and Turel, 2010). Moreover, a higher level of board IT governance is positively associated with organization performance, regardless of its IT mode (Turel and Bart, 2014). On top of that, it is worth noting that no clear methodology was used (or described) for the creation of the strategic impact grid. The classification was entirely based on the (extensive) experience of the 
authors. Lastly, it is difficult to position an organization in the grid as no guidelines are provided on how to classify the need for new or reliable IT as either high or low. Considering all these elements, we argue that the strategic impact grid is in need of further investigation.

In addition to the framework of Nolan and McFarlan (2005), other authors considered the factors that could influence board level IT governance. Besides the organization's need for new IT and its need for reliable IT, IT that supports the business versus IT that is the business (Coertze and von Solms, 2014), the IT intensity of the organization's industry (Yayla and Hu, 2014), internal versus external drivers and an operational versus a strategic focus (Raghupathi, 2007) are mentioned as influential factors. These factors all refer to the role of IT in an organization, but use different perspectives. Hence, there seems to be no clarity on how to define the role of IT in an organization.

Next to factors that refer to the role of IT, other organizational and board characteristics are put forward that impact the degree of involvement of the board in IT governance. Organization age, the proportion of insiders on the board, the board size, the IT competency of the board, firm performance and corporate governance seem to be correlated with the level of board IT governance (Benaroch and Chernobai, 2017; Jewer and McKay, 2012; Kambil and Lucas, 2002; Premuroso and Bhattacharya, 2007). However, these factors are only mentioned in descriptive research and are not put forward in prescriptive research as factors that boards should take into account when deciding how to shape their involvement in IT governance.

In conclusion, researchers seem to agree that board level IT governance should vary depending on the role of IT in the organization. However, how to define this role of IT remains uncertain. Moreover, other organizational and board attributes seem to influence board involvement in IT governance in practice. Yet, these contingencies are not included in prescriptive literature. 
These findings indicate that the contingencies of board level IT governance are in need of further research.

A contingency approach can also be found in IT governance research that does not specifically focus on the role of the board. Factors that are mentioned are the organization structure (centralized vs. decentralized), business strategy (defensive vs. aggressive), industry and firm size (A. E. Brown and Grant, 2005). Whereas earlier research on IT governance contingencies focused on the influence of individual factors, other researchers focused on multiple, interacting and conflicting contingencies. C. V. Brown and Magill (1994) for example identified ten interacting antecedents: corporate vision, corporate strategy, overall firm structure, culture - business unit autonomy, strategic IT role, senior management of IT, satisfaction with management of technology, satisfaction with use of technology, strategic grid of current/future applications and the locus of control for system approval/priority. Even more complex contingency frameworks were created that include multiple contingencies that differ across business units and/or IT services (C. V. Brown, 1997; C. V. Brown and Magill, 1998; Sambamurthy and Zmud, 1999). Prior research on contingencies influencing IT governance, can be used to examine the contingencies of the more specific board focus of IT governance.

\section{Gap 2: gap between prescriptive and descriptive research}

A major gap exists between prescriptive board level IT governance research - specifying how boards should operationalize their IT governance responsibilities - and descriptive research describing how boards currently operationalize their IT governance duties . While prescriptive literature stresses the importance of boards that engage in IT governance, descriptive literature shows that many boards are not as involved in IT governance as they should be. Perhaps even more surprising are the results of studies that examined board members' perceptions of the importance of board level IT governance. These perceptions do not match the current state of 
practice either, indicating that even though board members acknowledge the value of board level IT governance, they struggle with its implementation. Bart and Turel (2010) for example found a major discrepancy between the importance board members attach to questions they could ask about IT governance and the number of times they actually ask these questions. Similarly, Valentine and Stewart (2013a) found that while a vast majority of directors agreed on the importance of IT expertise at the board of directors, only $36.47 \%$ of these directors confirmed having one or more directors on their board with such expertise. On the other hand, many researchers advocate the implementation of an IT oversight or similar committee at the level of the board (Coertze and von Solms, 2014; Higgs, et al., 2016; Nolan and McFarlan, 2005; Oliver and Walker, 2006; Posthumus, et al., 2010; Premuroso and Bhattacharya, 2007; Read, 2004; Turel and Bart, 2014), while interviews with practitioners show that they do not always support this idea (Andriole, 2009; Jewer \& McKay, 2012).

This gap indicates that, for some reason, the guidance included in prescriptive literature does not find its way to practice. Indeed, the lack of guidance and understanding of board members of how to implement board level IT governance is mentioned by several authors as an inhibitor of board involvement in IT related decision-making and control (Coertze and von Solms, 2014; Parent and Reich, 2009; Posthumus and von Solms, 2008). We argue that both prescriptive and descriptive research exhibit gaps, which might result in the gap between prescriptive and descriptive research.

Descriptive research concerning board level IT governance currently includes reports of large data sets containing information on the mechanisms deployed and perceptions of board members resulting from surveys and interviews with individual board members. Two gaps can be identified in this research stream. First, a holistic approach towards IT governance is essential, as it includes a complex and dynamic mix of structures, processes and relational mechanisms (De Haes and Van Grembergen, 2015). However, none of the existing research 
reports on combinations of different mechanisms and how they interact. Second, researchers argue that the best way to implement board level IT governance depends on various factors. Hence, it is crucial to consider board level IT governance in its context. Consequently, it makes sense to use the case study method to analyze the state of practice, as it enables researchers to understand the full complexity of the situation and take into account the context of the organization (Yin, 2013).

On the other hand, taking a closer look at the board level IT governance mechanisms proposed in prescriptive literature, we found a gap exists here as well. The proposed practices were classified into structures, processes and relational mechanisms, as shown in Table 3 . While the structures are quite clear and described in detail, little was found about processes and relational mechanisms. The suggested process is asking IT-related questions. It remains unclear how boards should handle this process and what the relationship is with the IT governance structures at the level of the board. While relational mechanisms are often informal and less structured (Van Grembergen and De Haes, 2009), they are a crucial part of IT governance and an essential contributing factor to business/IT alignment (Callahan, Bastos, \& Keyes, 2004; Keil, Tiwana, \& Bush, 2002; Venkatraman, Henderson, \& Oldach, 1993; Weill and Broadbent, 1998). The limited number of such mechanisms found in the board level IT governance literature confirms the concern of Smits and van Hillegersberg (2014) that IT governance research exhibits a lack of focus on the human or social aspects of governance. Hence, relational mechanisms that can be implemented to increase the level of engagement of the board in IT governance should be a topic of future research.

\section{Gap 3: uncertainty about consequences}

Even though little research has been attributed to the consequences of board level IT governance, this is a crucial research area. The synthesis of current research points out that 
many of the approaches to increase board engagement in IT governance suggested in academic literature are considered important or useful by board members. However, few boards adopt these practices, illustrating there is a knowing-doing gap. The uncertainty about the consequences of board involvement in IT governance might reinforce this gap.

In their definition of IT governance, De Haes and Van Grembergen (2015) argue that IT governance mechanisms "enable both business and IT people to execute their responsibilities in support of business/IT alignment and the creation of business value from IT-enabled business investments." This means that IT governance, including IT governance at the level of the board, leads to the alignment of business and IT and in turn to an increase in business value from IT-enabled investments. This business/IT alignment entails the fit and integration of the business strategy, IT strategy, business structures and IT structures. As such, this definition contains two elements that need to be taken into account when examining the consequences of board level IT governance: alignment and business value.

Indeed, strategic alignment is a partial mediator between board level IT governance and organizational performance (Turel, et al., 2017). The influence of board level IT governance on business value coming from IT-enabled investments is less clear. The focus of the research on the consequences of board level IT governance seems to be on financial indicators, more specifically on the overall financial performance of the firm (Jewer and McKay, 2012; Turel and Bart, 2014; Turel, et al., 2017; Yayla and $\mathrm{Hu}$, 2014). The financial performance is measured using perceptions of directors concerning the firm's financial performance and its relative performance standing in its industry (Turel and Bart, 2014; Turel, et al., 2017), perceptions of the degree to which IT contributes to (1) return on investment, (2) sales revenue increase, (3) market share increase, (4) cost savings, (5) operating efficiency, (6) process improvement and (7) customer satisfaction (Jewer and McKay, 2012) and Tobin's q and market-to-book value ratio (Yayla and $\mathrm{Hu}, 2014$ ). However, the business value that originates 
from IT-enabled investments is not limited to financial matters, as a great deal of this value of is of a non-financial, intangible nature (Schryen, 2013). Indeed, recently, attempts were made to broaden the view on the consequences of board level IT governance to non-financial indicators such as innovation and reported security breaches (Héroux and Fortin, 2018; Higgs, et al., 2016). Yet, this stream of research remains quite limited.

Another important limitation of current research is the focus on examining the link between board level IT governance and firm performance directly. Different potential mediators and moderators can be identified that can contribute to the understanding of the consequences of increasing the engagement of the board in IT governance (Turel and Bart, 2014). Strategic alignment and governing styles are the only two moderators/mediators that have been studied so far (Héroux and Fortin, 2018; Turel, et al., 2017).

Schryen (2013) argues that there are two business value dimensions: internal value and competitive value. IS assets, IS capabilities and socio-organizational capabilities contribute to the internal value, while competitive value is obtained through the support by IT of firm performance, innovation and protection of resources. Indeed, applying the resource based view of the firm, IS assets and capabilities can be enhanced by including the right board members. Agency theory on the other hand confirms that it is the role of the board to check whether management has the right practices in place to ensure good governance of IT, which corresponds to the socio-organizational capabilities of the firm. As for the competitive value, current research confirms a positive link between board level IT governance and firm performance. As such, the model proposed by Schryen seems to be relevant to study the consequences of board level IT governance.

The discussion of these three gaps resulted in an agenda for future research, which is shown in Table 4. 
Agenda for future research

Gap 1: uncertainty about contingency factors

RQ 1: What are factors that influence the level of engagement of the board in IT governance?

RQ 1.1: How can the identified contingency factor for board level IT governance be operationalized?

RQ 1.2: What is the impact of the role of IT on board level IT governance?

RQ 1.3: What board characteristics influence board level IT governance?

RQ 1.4: What organization characteristics influence board level IT governance?

RQ 1.5: What industry characteristics influence board level IT governance?

Gap 2: gap between prescriptive and descriptive research

RQ 2: How do boards currently engage in board level IT governance?

RQ 2.1: Which combinations of structures, processes and relational mechanisms do boards of directors use to engage in board level IT governance?

RQ 2.2: What is the context in which board level IT governance mechanisms are deployed?

RQ 3: Which practices can be used to implement board level IT governance?

RQ 3.1: Which processes can be used to implement board level IT governance?

RQ 3.2: Which relational mechanisms can be used to implement board level IT governance?

Gap 3: uncertainty about consequences

RQ 4: What is the impact of board level IT governance on internal value?

RQ 4.1: What is the impact of board level IT governance on IS assets?

RQ 4.2: What is the impact of board level IT governance on IS capabilities?

RQ 4.3: What is the impact of board level IT governance on socio-organizational capabilities?

RQ 5: What is the impact of board level IT governance on competitive value?

RQ 5.1: What is the impact of board level IT governance on innovation?

RQ 5.2: What is the impact of board level IT governance on the protection of resources?

\section{Table 4 Agenda for future research}

\section{CONCLUSIONS}

We found that both researchers and practitioners agree that boards of directors can no longer delegate their IT governance related responsibilities. As digital transformation changes the bases of competition, the board needs to take accountability for IT-related strategic decision making and control. However, literature points out that in practice little boards engage in IT governance, pointing towards a knowing-doing gap. We conducted a scoping review to create an agenda for future research to address this gap. 32 papers that focus on the topic of board level IT governance were analyzed. The review was organized around three main issues: (1) the antecedents of board level IT governance, (2) governance practices that can be used to increase the engagement of the board in IT governance and (3) the consequences of board level IT governance. 
Many antecedents of board level IT governance are put forward in academic literature. One of the most frequently mentioned ones is the role of IT in the organization. The definition of the role of IT varies among different papers, but the basic idea is the same. That is, the more an organization relies on IT for its operations and/or innovation, the more the board should engage in digital oversight. The lack of IT expertise within the boardroom is by far the most widely mentioned inhibitor of engagement of the board in IT governance. Other factors include firm performance, corporate governance, the fact that boards just do not know how to engage in IT governance, motivational factors, IT governance structures and practices below the board, board characteristics like board size and director age and trends that portray IT as having strategic importance. Despite this long list of hypothesized antecedents, little empirical research exists that confirms the influence of these factors.

With regard to the question of how to implement IT governance at the level of the board, the majority of research refers to structures. Structures proposed are an IT oversight or similar committee and IT expertise at the level of the board. The CIO also seems to play a vital role in increasing the engagement of the board in IT governance. That is, the CIO being part of the (executive) board and the CIO reporting to the CEO could facilitate board level IT governance. Less clarity exists about possible processes boards could implement. Asking IT-related questions is the only process that was found in board level IT governance literature. Suggestions regarding relational mechanisms are scarce and quite briefly described as well, with effective communication about IT from and to the board and the CIO regularly meeting with the board being the only two mechanisms that were mentioned.

Research confirms the benefits of board level IT governance. Higher levels of board IT governance lead to increased organizational performance and improved risk management. On top of that, board involvement in IT governance has a positive effect on strategic alignment. In fact, strategic alignment is a partial mediator between board level IT governance and 
organizational performance. The effects on organizational performance are moderated through authoritarian governance style and IT intensity of the firm.

We concluded that, still, some gaps exist concerning our three research questions, which need to be addressed in order to be able to close the above-mentioned knowing-doing gap. First of all, uncertainty exists about contingency factors. Researchers seem to agree that the best way to implement board level IT governance depends on various factors. However, it is unclear which contingency factors should be considered and how they can be defined. Second, a major gap exists between prescriptive and descriptive research with regard to how to implement IT governance at the level of the board. At the same time, little research reports on the current state-of-practice. Especially research on how specific organizations combine different board level IT governance practices is non-existent. The last gap we found is the uncertainty about the consequences of board level IT governance. That is, current research focusses on financial benefits, without taking into account other aspects of business value. Furthermore, the link between board level IT governance and firm performance is examined directly. However, different variables can mediate or moderate this link. Identifying these variables can contribute to our understanding of the consequences of increasing the engagement of the board in IT governance.

Given the many loose ends in board level IT governance research, this research topic is in need of additional exploratory research. More specifically, we consider opening up the black box of how boards currently engage in digital oversight to be one of the key challenges of future research. Case study research might be most suitable as it will enable the researcher to capture a holistic view of IT governance practices. Furthermore, we adopted the perspective of structures, processes and relational mechanisms, yet, other viewpoints are provided by Hoogervorst (2009) and Ciborra, et al. (2000), who specifically focus on dealing with the complexity and dynamics associated with IT. Future research could adopt such a specific focus 
and examine how boards of directors should deal with these issues. With regard to researching the consequences of board level IT governance, we recommend supplementing the existing research based on variance theory with process theories, as this will provide a richer view on the consequences of board level IT governance. Other potential paths for future research are summarized in the research agendas we provided for each of the identified gaps. We hope that this review will trigger more research on the current and pivotal topic of board level IT governance.

\section{NOTES ON CONTRIBUTORS}

Laura Caluwe, FWO SB PhD fellow, is a PhD candidate in Information Technology Governance at the department of Management Information Systems of the Faculty of Applied Economics at the University of Antwerp. She has a bachelor's and master's degree in Business Engineering: Management Information Systems from the University of Antwerp. Her research interests include IT governance and management, and Business/IT alignment.

Steven De Haes, $\mathrm{PhD}$, is a Full Professor in Information Systems Management at the University of Antwerp (Faculty of Applied Economics) and Dean of Antwerp Management School. He is actively engaged in teaching and applied research in the domains of Digital Strategies, IT Governance and Management, IT Strategy and Alignment, IT Value and Performance Management, IT Assurance and Audit, and Information Risk and Security. 


\section{References}

Andriole, S. J. (2009). Boards of directors and technology governance: The surprising state of the practice. Communications of the Association for Information Systems, 24(1), p 22.

Arksey, H., \& O'Malley, L. (2005). Scoping studies: towards a methodological framework. International journal of social research methodology, 8(1), pp. 19-32.

Bart, C., \& Turel, O. (2010). IT and the board of directors: An empirical investigation into the "governance questions" Canadian board members ask about IT. Journal of Information Systems, 24(2), pp. 147-172.

Benaroch, M., \& Chernobai, A. (2017). Operational IT failures, IT value-destruction, and board-level IT governance changes. MIS quarterly, 41(3), pp. 729-762.

Best, P., \& Buckby, S. (2007). Development of a Board IT Governance (ITG) Review Model. 2007 Accounting \& Finance Association of Australia and New Zealand Conference (AFAANZ 2007), Gold Coast, Australia.

Brown, A. E., \& Grant, G. G. (2005). Framing the frameworks: A review of IT governance research. Communications of the Association for Information Systems, 15(1), p 38.

Brown, C. V. (1997). Examining the emergence of hybrid IS governance solutions: Evidence from a single case site. Information systems research, 8(1), pp. 69-94.

Brown, C. V., \& Magill, S. L. (1994). Alignment of the IS functions with the enterprise: toward a model of antecedents. MIS quarterly, 18(4), pp. 371-403.

Brown, C. V., \& Magill, S. L. (1998). Reconceptualizing the context-design issue for the information systems function. Organization science, 9(2), pp. 176-194.

Butler, R., \& Butler, M. J. (2010). Beyond King III: Assigning accountability for IT governance in South African enterprises. South African Journal of Business Management, 41(3), pp. 33-45.

Callahan, J., Bastos, C., \& Keyes, D. (2004). The evolution of IT Governance at NB Power. In W. Van Grembergen (Ed.), Strategies for information technology governance (pp. 343356). Hershey, PA: Idea Group Publishing.

Canadian Institute for Chartered Accountants (CICA). (2004). 20 Questions Directors Should Ask About IT. Toronto, ON: CICA.

Canadian Institute for Chartered Accountants (CICA). (2012). 20 Questions Directors Should Ask About IT Second Edition. Toronto, ON: CICA.

Ciborra, C., Braa, K., Cordella, A., Hepsø, V., Dahlbom, B., Failla, A., \& Hanseth, O. (2000). From control to drift: the dynamics of corporate information infastructures Oxford: Oxford University Press on Demand.

Coertze, J., \& Von Solms, R. (2013). The Board and IT Governance: A Replicative Study. African Journal of Business Management, 7(36), $\mathrm{p} 3358$.

Coertze, J., \& von Solms, R. (2014). The Board and CIO: The IT Alignment Challenge. 2014 47th Hawaii International Conference on System Sciences, Waikoloa, HI.

Corbin, J., Strauss, A., \& Strauss, A. L. (2014). Basics of qualitative research Thousand Oaks, CA: Sage.

Daily, C. M., Dalton, D. R., \& Cannella, A. A. (2003). Corporate governance: Decades of dialogue and data. Academy of management review, 28(3), pp. 371-382.

Daudt, H. M., van Mossel, C., \& Scott, S. J. (2013). Enhancing the scoping study methodology: a large, inter-professional team's experience with Arksey and O'Malley's framework. BMC medical research methodology, 13(1), p 48.

De Haes, S., \& Van Grembergen, W. (2009). An Exploratory Study into IT Governance Implementations and its Impact on Business/IT Alignment. [Article]. Information Systems Management, 26(2), pp. 123-137. 
De Haes, S., \& Van Grembergen, W. (2015). Enterprise governance of information technology: Springer.

Eisenhardt, K. M. (1988). Agency-and institutional-theory explanations: The case of retail sales compensation. Academy of management Journal, 31(3), pp. 488-511.

Eisenhardt, K. M. (1989). Agency theory: An assessment and review. Academy of management review, 14(1), pp. 57-74.

Forbes, D. P., \& Milliken, F. J. (1999). Cognition and corporate governance: Understanding boards of directors as strategic decision-making groups. Academy of management review, 24(3), pp. 489-505.

Hermalin, B. E., \& Weisbach, M. S. (2003). Boards of Directors as an Endogenously Determined Institution: A Survey of the Economic Literature (Digest Summary). Economic Policy Review, 9, pp. 7-26.

Héroux, S., \& Fortin, A. (2018). The moderating role of IT-business alignment in the relationship between IT governance, IT competence, and innovation. Information Systems Management, 35(2), pp. 98-123.

Higgs, J. L., Pinsker, R. E., Smith, T. J., \& Young, G. R. (2016). The relationship between board-level technology committees and reported security breaches. Journal of Information Systems, 30(3), pp. 79-98.

Hillman, A. J., \& Dalziel, T. (2003). Boards of directors and firm performance: Integrating agency and resource dependence perspectives. Academy of management review, 28(3), pp. 383-396.

Hoogervorst, J. A. (2009). Enterprise governance and enterprise engineering Heidelberg: Springer.

Huse, M. (2005). Accountability and creating accountability: A framework for exploring behavioural perspectives of corporate governance. British Journal of Management, 16(s1), pp. S65-S79.

IT Governance Institute (ITGI). (2003). Board Briefing on IT Governance, 2nd Edition. Retrieved from https://www.isaca.org/knowledgecenter/research/researchdeliverables/pages/board-briefing-on-it-governance-2ndedition.aspx

Jensen, M. C., \& Meckling, W. H. (1976). Theory of the firm: Managerial behavior, agency costs and ownership structure. Journal of financial economics, 3(4), pp. 305-360.

Jewer, J., \& McKay, K. N. (2012). Antecedents and Consequences of Board IT Governance: Institutional and Strategic Choice Perspectives. Journal of the Association for Information Systems, 13(7), pp. 581-617.

Johnson, J. L., Daily, C. M., \& Ellstrand, A. E. (1996). Boards of directors: A review and research agenda. Journal of management, 22(3), pp. 409-438.

Kambil, A., \& Lucas, H. C. (2002). The board of directors and the management of information technology. Communications of the Association for Information Systems, 8(1), p 26.

Keil, M., Tiwana, A., \& Bush, A. (2002). Reconciling user and project manager perceptions of IT project risk: a Delphi study. Information Systems Journal, 12(2), pp. 103-119.

Kitchenham, B., \& Charters, S. (2007). Guidelines for performing systematic literature reviews in software engineering. Keele: K. U. a. U. o. Durham.

Kritzinger-von Solms, E., \& Strous, L. A. M. (2003). Information security: A corporate governance issue Integrity and Internal Control in Information Systems V (Vol. 124, pp. 115-133).

Kuruzovich, J., Bassellier, G., \& Sambamurthy, V. (2012). IT governance processes and IT alignment: Viewpoints from the board of directors. 45th Hawaii International Conference on System Science (HICSS), Kauai, HI. 
Levac, D., Colquhoun, H., \& O'Brien, K. K. (2010). Scoping studies: advancing the methodology. Implementation Science, 5(1), p 69.

Mähring, M. (2006) The role of the board of directors in IT governance: A review and agenda for research. Paper presented at the AMCIS 2006 Proceedings, Acapulco, Mexico.

Mohamad, S., Hendrick, M., O'Leary, C., \& Best, P. (2014). Developing a model to evaluate the information technology competence of boards of directors. Corporate Ownership \& Control, 12(1), p 12.

Nolan, R., \& McFarlan, F. W. (2005). Information technology and the board of directors. Harvard Business Review, 83(10), pp. 96-+.

O'Donnell, E. (2004). Discussion of director responsibility for IT governance: a perspective on strategy. International Journal of Accounting Information Systems, 5(2), pp. 101-104.

Oliver, G. R., \& Walker, R. G. (2006). Reporting on software development projects to senior managers and the board. Abacus-a Journal of Accounting Finance and Business Studies, 42(1), pp. 43-65.

Parent, M., \& Reich, B. H. (2009). Governing Information Technology Risk. California Management Review, 51(3), pp. 134-+.

Peterson, R. (2004). Crafting information technology governance. Information Systems Management, 21(4), pp. 7-22.

Posthumus, S., \& von Solms, R. (2008). Agency theory: Can it be used to strengthen IT governance? 23rd IFIP International Information Security Conference, Milano, Italy.

Posthumus, S., von Solms, R., \& King, M. (2010). The board and IT governance: The what, who and how. South African Journal of Business Management, 41(3), pp. 23-32.

Premuroso, R. F., \& Bhattacharya, S. (2007). Is there a relationship between firm performance, corporate governance, and a firm's decision to form a technology committee? Corporate Governance: An International Review, 15(6), pp. 1260-1276.

Raghupathi, W. (2007). Corporate Governance of IT: A Framework For Development. Communications of the ACM, 50(8), pp. 94-99.

Read, T. J. (2004). Discussion of director responsibility for IT governance. International Journal of Accounting Information Systems, 5(2), pp. 105-107.

Sambamurthy, V., \& Zmud, R. W. (1999). Arrangements for information technology governance: A theory of multiple contingencies. MIS quarterly, 23(2), pp. 261-290.

Schryen, G. (2013). Revisiting IS business value research: what we already know, what we still need to know, and how we can get there. European Journal of Information Systems, 22(2), pp. 139-169.

Smits, D., \& van Hillegersberg, J. (2014). The development of an IT governance maturity model for hard and soft governance. Proceedings of the 8th European conference on IS management and evaluation-ECIME 2014, Ghent, 1112 September 2014.

Smits, D., \& van Hillegersberg, J. (2015). IT Governance maturity: developing a maturity model using the Delphi method. 48th Hawaii International Conference on System Sciences (HICSS), 2015 Kauai, HI.

Sohal, A. S., \& Fitzpatrick, P. (2002). IT governance and management in large Australian organisations. International Journal of Production Economics, 75(1-2), pp. 97-112.

Stinchcombe, A. L., \& March, J. (1965). Social structure and organizations. Handbook of organizations, 7, pp. 142-193.

Thorp, J. (2003). The information paradox: realizing the business benefits of information technology Toronto, ON: McGraw-Hill Ryerson.

Tolbert, P. S., \& Zucker, L. G. (1983). Institutional sources of change in the formal structure of organizations: The diffusion of civil service reform, 1880-1935. Administrative science quarterly, 28(1), pp. 22-39. 
Tosi Jr, H. L., \& Slocum Jr, J. W. (1984). Contingency theory: Some suggested directions. Journal of management, 10(1), pp. 9-26.

Trautman, L. J., \& Altenbaumer-Price, K. (2010). The board's responsibility for information technology governance. J. Marshall J. Computer \& Info. L., 28(3), p 313.

Trites, G. (2004). Director responsibility for IT governance. International Journal of Accounting Information Systems, 5(2), pp. 89-99.

Turel, O., \& Bart, C. (2014). Board-level IT governance and organizational performance. European Journal of Information Systems, 23(2), pp. 223-239.

Turel, O., Liu, P., \& Bart, C. (2017). Board-Level Information Technology Governance Effects on Organizational Performance: the Roles of Strategic Alignment and Authoritarian Governance Style. Information Systems Management, 34(2), pp. 117-136.

Valentine, E., \& Stewart, G. (2013a). Director competencies for effective enterprise technology governance. Proceedings of the 24th Australasian Conference on Information Systems (ACIS 2013), Melbourne, Australia.

Valentine, E., \& Stewart, G. (2013b). The emerging role of the board of directors in enterprise business technology governance. International Journal of Disclosure and Governance, 10(4), pp. 346-362.

Valentine, E., \& Stewart, G. (2015) Enterprise Business Technology Governance: Three Competencies to Build Board Digital Leadership Capability. Paper presented at the 2015 48th Hawaii International Conference on System Sciences, Kauai, HI. <Go to ISI >://WOS:000366264104076

Van Grembergen, W., \& De Haes, S. (2009). Enterprise governance of information technology: achieving strategic alignment and value New York, NY: Springer.

Venkatraman, N., Henderson, J. C., \& Oldach, S. (1993). Continuous strategic alignment: Exploiting information technology capabilities for competitive success. European Management Journal, 11(2), pp. 139-149.

Webster, J., \& Watson, R. T. (2002). Analyzing the past to prepare for the future: Writing a literature review. MIS quarterly, 26(2), pp. xiii-xxiii.

Weill, P., \& Broadbent, M. (1998). Leveraging the New Infrastructure: How Market Leaders Capitalize on Information Technology Boston, MA: Harvard Business Review Press.

Weill, P., \& Ross, J. W. (2004). IT governance: How top performers manage IT decision rights for superior results Boston, MA: Harvard Business Press.

Wilkin, C. L., \& Chenhall, R. H. (2010). A review of IT governance: A taxonomy to inform accounting information systems. Journal of Information Systems, 24(2), pp. 107-146.

Yayla, A. A., \& Hu, Q. (2014). The effect of Board of directors' IT awareness on CIO compensation and firm performance. Decision Sciences, 45(3), pp. 401-436.

Yin, R. K. (2013). Case study research: Design and methods Los Angeles, CA: Sage publications. 